January 2021

\title{
Federal Jurisdiction as Statutory Interpretation: A Majordomo Purposivist Perspective
}

\author{
Martin H. Redish \\ Northwestern University School of Law \\ Andrew F. Rodheim \\ Sidley Austin LLP \\ Nicholas Roosevelt \\ J. Abrams Law, PC
}

\section{Recommended Citation}

Martin H. Redish et al., Federal Jurisdiction as Statutory Interpretation: A Majordomo Purposivist

Perspective, 74 SMU L. REV. 303 (2021)

https://scholar.smu.edu/smulr/vol74/iss2/8

This Article is brought to you for free and open access by the Law Journals at SMU Scholar. It has been accepted for inclusion in SMU Law Review by an authorized administrator of SMU Scholar. For more information, please visit http://digitalrepository.smu.edu. 


\title{
Federal Jurisdiction as Statutory INTERPRETATION: A MAJORDOMO Purposivist Perspective
}

\author{
Martin H. Redish,* Andrew F. Rodheim,** Nicholas Roosevelt***
}

\begin{abstract}
The study of federal jurisdiction has traditionally involved little more than a combined examination of judicial doctrine and policy. Under this approach, scholars study how the Supreme Court has decided to shape the jurisdiction of the federal courts, and the policies the Court believes jurisdictional doctrine should reflect. Hardly ever have scholars studied the legislative purposes sought to be achieved by federal jurisdiction. It is important to recall, however, that for the most part, modern federal jurisdiction law grows out of a network of congressional statutes-which, in turn, grow out of policy choices made not by unrepresentative judges but by those politically accountable to the populace. It is also important to realize that since the federal courts enforce substantive federal law, jurisdictional directives often operate as the fundamental means by which to implement the substantive policy choices made by the political branches. It is for these reasons that we believe federal jurisdiction should be studied, in the first instance, not merely as a matter of doctrinal and policy analysis but rather as a matter of statutory construction, as a means of implementing the goals chosen by those elected by the people. Such an approach, after all, reflects the nation's foundational commitment to democracy. In this Article, we seek to achieve two goals: First, to explain how the Supreme Court's general failure to view the shaping of federal jurisdiction as fundamentally a matter of statutory construction has dangerously distorted the central premises of American political theory, and second, to propose an original approach to the "faithful agent" model of statutory interpretation-what we call the "Majordomo Purposivist" approach. By comparing the role of an interpreting judge to that of a majordomo—traditionally, one in charge of a large estate owned by another-we seek both to confine and broaden the judge's authority. We confine it by underscoring the interpretive humility a judge must demonstrate in interpreting statutes enacted by a

* Louis and Harriet Ancel Professor of Law and Public Policy, Northwestern University Pritzker School of Law. The authors would like to express their sincere thanks to James Pfander, Zachary Clopton, and Aaron-Andrew Bruhl for their valuable comments on this Article. All views expressed, as well as any mistakes, are the sole responsibility of the authors.

** B.A., J.D. Northwestern University.

*** A.B., University of Pennsylvania; J.D., Northwestern University.
\end{abstract}


representative, accountable governing body. Yet we simultaneously broaden that authority by recognizing that, much like a real-life majordomo, the interpreting judge will often have a significant degree of implementational discretion in determining how best to achieve legislative goals in particular situations.

\section{TABLE OF CONTENTS}

I. INTRODUCTION . .......................... 304

II. THE TRADITIONAL UNDERSTANDING OF FEDERAL JURISDICTION AS CONGRESSIONAL RESPONSIBILITY ......................... 308

III. FEDERAL JURISDICTION, THE DIALOGIC APPROACH, AND THE PARTNERSHIP MODEL OF STATUTORY INTERPRETATION ................. 311

A. Absence of Constitutional Basis............. 313

B. The Dialogic Approach, Democratic Theory, and Separation of Powers ..................... 315

C. The Dialogue Myth .......................... 317

1. Sequence of Independent Actions, Not a Dialogue . 317

2. Fallacy of the Assumption of Congressional Silence as Acquiescence ........................... 318

3. A Rigged Dialogue: Making the Court the Ultimate Authority................................. 319

4. A Disingenuous Dialogue .................. 321

IV. THE THEORY OF STATUTORY INTERPRETATION AS INTERPRETATION: THE JUDGE AS A

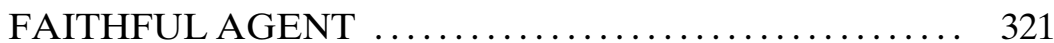

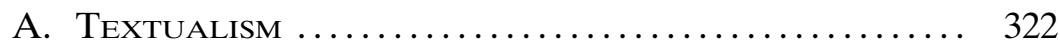

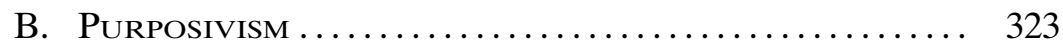

C. The Majordomo Conception of Purposivism...... 325

V. APPLYING MAJORDOMO PURPOSIVISM TO

FEDERAL JURISDICTION STATUTES ............ 328

A. Federal Question Jurisdiction ................ 329

1. The Scope of "Arising Under" Jurisdiction........ 331

2. The "Well-Pleaded Complaint" Rule............. 338

B. Diversity Jurisdiction ....................... 345

1. The Complete Diversity Requirement ........... 349

2. Citizenship of Unincorporated Entities ........... 351

3. Jurisdictional Amount and Aggregation of Claims . 355

VI. CONCLUSION ................................... 358

\section{INTRODUCTION}

CHOLARS have long debated the relative roles of Congress and the Court in determining the extent of federal courts' jurisdiction. 1 The Framers of the Constitution drafted Article III to explicitly leave to Congress the decision whether to establish inferior federal 
courts. The Supreme Court has long understood that this Article III authority also gives Congress a more general power-within the Constitution's bounds-to control the scope of federal jurisdiction. ${ }^{1}$ In exercising that power, Congress has passed statutes granting the federal courts jurisdiction. Most notably, Congress has vested federal courts with jurisdiction over those issues that arise under federal law $^{2}$ and over causes of action that arise between litigants from different states. ${ }^{3}$ Federal courts, in determining whether they may exercise federal question or diversity jurisdiction in a particular instance, must interpret those statutes. Thus, at the heart of the Court's jurisdictional doctrine is a debate over statutory interpretation.

Over time, the Court has developed complex doctrines of federal jurisdiction through its interpretations of both the federal question and diversity jurisdiction statutes. But in determining the scope of federal courts' jurisdiction, the Court often usurps legislative authority, ignoring Congress's original goals in passing the statutes and instead creating doctrine based on its own policy preferences. And at other times, the Court has hidden its own jurisdictional policy preferences behind a shield of what it describes as rigorous adherence to legislative directives, which in reality are more imaginary than real. This Article rejects this method of statutory interpretation, which effectively, if furtively, views the judiciary as an equal partner with Congress in interpreting congressional statutes. Instead, we emphasize the judiciary's role as Congress's faithful agent-a charge that requires the judiciary to always seek to effectuate congressional purpose as it best understands it.

Some might suggest that our approach improperly ignores the important independent role played by the judiciary in shaping federal jurisdiction. To be sure, the courts play a vital role in reviewing the constitutionality of federal jurisdictional statutes, just as they do in exercising judicial review over all actions of the political branches of the federal government. Short of that important function, however, the judiciary's role is purely a subservient and interpretive one for two key reasons. First, the history of the Constitution's drafting, as well as its text, demonstrates that the Framers intended Congress to play a primary role in the shaping of federal court authority. Second, and arguably even more significant, is the fundamental precept of American democracy: that constitutionally valid governmental policy choices are made by those representative of, and accountable to, the populace. The intersection between democratic theory and federal court jurisdiction is not difficult to understand. Federal courts are necessary vehicles to interpret and enforce federal statutes. Those statutes, in turn, represent policy choices enacted

1. See infra notes 21-24 and accompanying text.

2. 28 U.S.C. $§ 1331$ ("The district courts shall have original jurisdiction of all civil actions arising under the Constitution, laws, or treaties of the United States.").

3. 28 U.S.C. $\$ 1332(a)(1)$ ("The district courts shall have original jurisdiction of all civil actions where the matter in controversy exceeds the sum or value of $\$ 75,000$, exclusive of interest and costs, and is between citizens of different States."). 
through the process of bicameralism and presentment, a process that reflects the choices of those elected by the populace. If the democratic process is to function in its intended manner, the unaccountable and unrepresentative federal courts must play no role in questioning or second-guessing those choices, short of a finding of unconstitutionality. Yet, were federal courts allowed to restrict constitutionally valid federal court jurisdiction in a manner not contemplated by those who enacted the jurisdictional statutes, implementation of substantive legislative choices by the most expert court system could be considerably undermined. This, in turn, could substantially disrupt attainment of substantive policy goals established by the politically accountable branches.

This does not mean, however, that the judiciary's role in shaping federal jurisdiction is either minimal or mechanistic. Rather, the courts' role is as interpreter, and, in the case of most jurisdictional statutes, which are broadly framed, that role is a significant one. As we will show, the judicial role in interpreting such statutes is, paradoxically, both a subservient and creative one. It is subservient in the sense that the interpreting court must recognize that the foundational policy choices being enforced in the jurisdictional statutes are those of the representative branches and not their own. The interpreting court's first and foremost obligation, then, is to discern as best it can what the underlying legislative policy choices were in enacting that statute. It must do so by use of some sort of reverse-engineering process. But in the case of broadly phrased statutes, determination of exactly how to interpret the statute's directives in the most effective manner to achieve those goals lies largely (within the confines of plain text) in the hands of the interpreting court. In this sense, the court's interpretive role is creative.

We analogize this paradoxical "subservient-creative" role played by the court in interpreting and applying jurisdictional statutes to the concept of a "majordomo" - the individual in charge of the day-to-day operation of a large estate, usually owned by an absentee owner. In such a situation, the owner will likely have given the majordomo some broad directives as to how she wishes the estate to be run. But those directives will often say nothing explicitly about specific issues that may arise. Accordingly, majordomos will be called upon to employ both their ability to understand the owner's directives and their creativity in determining how best to achieve the owner's goals in any particular situation. It is this version of a purposivist "faithful agent" model of statutory interpretation that we adopt as the appropriate means of implementing the democratic model of policymaking in the context of jurisdictional statutes.

The Article begins by discussing the traditional understanding that Congress, not the judiciary, is responsible for regulating federal jurisdiction, creating grants of jurisdiction, and determining foundational jurisdictional policy. ${ }^{4}$ In Part III, the Article critically examines what we

4. See infra Part II. 
consider to be the seriously flawed approach to jurisdictional policymaking proposed by a respected scholar, Professor Barry Friedman, in his socalled dialogic model. ${ }^{5}$ Professor Friedman argues that the judiciary and Congress should be deemed to act as partners in determining the scope of federal jurisdiction through a "dialogue."6 To Professor Friedman, Congress and the federal courts develop jurisdictional policy together on a case-by-case basis. ${ }^{7}$ Neither stands in a superior position to the other. The Part concludes that the dialogic approach is fatally flawed because it effectively authorizes the judiciary to usurp congressional policymaking authority. As a matter of democratic theory, questions of federal jurisdiction-short of issues of constitutionality-are to be made by the democratically elected branches. ${ }^{8}$ It is the job of Congress to create jurisdictional policy, and the job of the courts to implement those choices. While, as will be shown, there is often significant room for the courts to contribute to the shaping of federal jurisdiction, this practice must come on a subservient, implementational level.

Part IV explores the nature and scope of this faithful agent theory of statutory interpretation. First, it discusses two traditional faithful agent methods of statutory interpretation: textualism ${ }^{9}$ and purposivism. ${ }^{10}$ As will be shown, neither of these methods sufficiently describes the judiciary's proper role in interpreting statutes. Rejecting textualism and traditional purposivism, we instead propose a refocused approach, which we call "majordomo purposivism." 11 We then explore the approach's grounding in American political theory as well as its essential elements.

Finally, in Part V, the Article examines the two statutory cornerstones of modern federal jurisdiction, federal question and diversity jurisdiction, analyzing both jurisdictional headings through the lens of the majordomo purposivist approach. ${ }^{12}$ Employing this method as a measure of current judicial doctrine under both $\S \S 1331$ and 1332 shows that much of the Court's current doctrine must be either rejected or reconceived. Far too often, the Court has failed to serve as anything even close to Congress's faithful agent in determining the scope of federal courts' jurisdiction. Instead, it has either usurped legislative authority by inserting its own policy considerations or hidden its own jurisdictional policy preferences behind a supposed adherence to nonexistent legislative directives. In contrast,

5. See infra Part III; Barry Friedman, A Different Dialogue: The Supreme Court, Congress and Federal Jurisdiction, 85 Nw. U. L. Rev. 1, 49 (1990).

6. Friedman, supra note 5, at 48-49.

7. See infra notes 41-49 and accompanying text.

8. See infra notes 26-31 and accompanying text.

9. See infra Section IV.A.

10. See infra Section IV.B.

11. See infra Section IV.C. We understand majordomo as describing " $[\mathrm{t}]$ he head steward or butler in the household of a sovereign or great noble." Majordomo, THE AMERICAN Heritage Dictionary of the English Language (4th ed. 2000). Popular depictions of majordomos include Higgins from the television show Magnum, P.I., Cogsworth from Disney's Beauty and the Beast, and Zazu from The Lion King, who actually introduces himself as "the king's majordomo." THE LiON KING (Disney 1994).

12. See infra Part V. 
under a majordomo purposivist approach, a judge must carefully consider both the relevant text and context of the statute and choose an interpretation that best effectuates Congress's purposes as the judge reasonably understands them. Thus, the majordomo purposivist approach to statutory interpretation aims to reemphasize Congress's role in controlling federal jurisdiction and spur a more focused discussion about what it means for a judge to function as a faithful agent of Congress. To be sure, in a number of instances there will not be a clear answer to these inquiries, and reasonable people might differ (though as our analysis will show, often the answer to the question of congressional purpose under the majordomo purposivist approach is glaringly obvious). But at the very least, the interpreting court would be asking the right questions.

\section{THE TRADITIONAL UNDERSTANDING OF FEDERAL JURISDICTION AS CONGRESSIONAL RESPONSIBILITY}

In drafting Article III, the Framers disagreed as to the necessity of inferior federal courts. ${ }^{13}$ While the Framers agreed that a Supreme Court was necessary, some members of the Constitutional Convention proposed that Article III mandate inferior federal courts, while others submitted proposals with no lower federal courts. ${ }^{14}$ Opponents of lower federal courts argued that litigation should be a state court responsibility. ${ }^{15}$ They maintained that state courts could adjudicate federal rights without problem and stressed that litigants could appeal state court holdings to the federal Supreme Court in order to assure uniformity. ${ }^{16}$ In contrast, advocates of lower federal courts argued that the government could not function without them. ${ }^{17}$ Eventually, those on opposite sides of the debate reached the "Madisonian Compromise."18 As a result of this agreement, inferior courts were not mandated by the Constitution, but instead, Congress was given the option to create lower federal courts. ${ }^{19}$ Thus, when all was said and done, Article III provided Congress full discretionary control over whether to create lower federal courts. ${ }^{20}$

13. Martin H. Redish \& Curtis E. Woods, Congressional Power to Control the Jurisdiction of Lower Federal Courts: A Critical Review and a New Synthesis, 124 U. PA. L. Rev. 45, 52-54 (1975).

14. Id. at 52 .

15. Id. at 53 .

16. Id. at $53-54$.

17. James Madison contended that the government without "[a]n effective Judiciary . . would be the mere trunk of a body without arms or legs to act or move." Id. at 53 (quoting 1 The Records of the Federal Convention of 1787, at 124 (Max Farrand ed., 1911)).

18. Id. at 54

19. Id.

20. U.S. Const. art. III, $\S 1$ ("The judicial Power of the United States, shall be vested in one supreme Court, and in such inferior Courts as the Congress may from time to time ordain and establish."). It is also relevant to note that Congress also has the power to make exceptions to the Supreme Court's appellate jurisdiction. See U.S. Const. art. III, § 2, cl. 2 ("[T]he supreme Court shall have appellate Jurisdiction ... with such Exceptions . . . as the Congress shall make.”); Ex parte McCardle, 74 U.S. (7 Wall.) 506, 513 (1868). 
Since the nineteenth century, the Court has recognized that pursuant to this Compromise, Article III gives Congress more power than simply determining whether lower federal courts exist. In the 1850 case Sheldon $v$. Sill, the Court held that "Congress, having the power to establish the [federal] courts, must define their respective jurisdictions." 21 The Court stressed that "[c]ourts created by statute can have no jurisdiction but such as the statute confers." 22 The Court advanced a principle of "greater includes the lesser": because Congress has the greater power of discretionary authority to create lower federal courts, Congress logically possesses the lesser authority to abolish the lower courts in a partial manner. ${ }^{23}$ It also follows, therefore, that Congress has the responsibility and authority to control the scope of federal courts' jurisdiction. ${ }^{24}$ For the most part, scholars agree with the traditional greater includes the lesser approach, recognizing that Congress has the authority to abolish lower federal courts in a partial manner and control the scope of lower federal courts' jurisdiction. ${ }^{25}$

In addition to the greater includes the lesser directive of Article III, vesting in Congress the responsibility for determining federal court jurisdiction is consistent with traditional principles of democratic theory and separation of powers. The Framers of the Constitution emphasized the importance of separation of powers among the three branches of govern-

21. Sheldon v. Sill, 49 U.S. (8 How.) 441, 448 (1850).

22. Id. at 449 .

23. Id. (holding that because Congress "ha[s] a right to prescribe [jurisdiction], Congress may withhold from any court of its creation jurisdiction"); see also Lockerty v. Phillips, 319 U.S. 182, 187 (1943) ("The Congressional power to ordain and establish inferior courts includes the power 'of investing them with jurisdiction either limited, concurrent, or exclusive, and of withholding jurisdiction from them in the exact degrees and character which to Congress may seem proper for the public good." " (quoting Cary v. Curtis, 44 U.S. (3 How.) 236, 245 (1845))).

24. See, e.g., Bowles v. Russell, 551 U.S. 205, 212 (2007) ("Within constitutional bounds, Congress decides what cases the federal courts have jurisdiction to consider."); R.R. Co. v. Mississippi, 102 U.S. 135, 141 (1880) ("[T]he judicial power of the United States is to be exercised . . . as the wisdom of Congress may direct . . .."); Cary, 44 U.S. (3 How.) at 245 ("[T]he judicial power of the United States . . . is . . . dependent for its distribution and organization, and for the modes of its exercise, entirely upon the action of Congress .....").

25. See, e.g., Martin H. Redish, Suzanna Sherry \& James E. Pfander, Federal Courts 104 (7th ed. 2012) ("Article III of the Constitution . . . confers broad power on Congress to regulate the jurisdiction of the federal courts."); Redish \& Woods, supra note 13 , at 56 ("[T]he compromise reached as to the creation of the inferior courts was interpreted to extend also to the conferral of jurisdiction upon them."); F. Andrew Hessick III, The Common Law of Federal Question Jurisdiction, 60 AlA. L. Rev. 895, 901 (2009) ("Courts and commentators agree that Congress's power to create inferior courts carries with it the power to prescribe the jurisdiction of those courts within the limits of Article III."); Michael Wells, Congress's Paramount Role in Setting the Scope of Federal Jurisdiction, 85 Nw. U. L. Rev. 465, 473-74 (1991). To be sure, several respected scholars, such as Akhil Amar and Lawrence Sager, disagree and contend that Congress cannot restrict lower federal courts in a partial manner. See, e.g., Akhil Reed Amar, A Neo-Federalist View of Article III: Separating the Two Tiers of Federal Jurisdiction, 65 B.U. L. REv. 205, 224 (1985); Lawrence Gene Sager, Foreword: Constitutional Limitations on Congress' Authority to Regulate the Jurisdiction of the Federal Courts, 95 Harv. L. Rev. 17, 38 (1981). Nevertheless, since Sheldon, the Supreme Court has been largely consistent in adhering to the traditional greater includes the lesser approach. 
ment. ${ }^{26}$ Congress, unlike the federal judiciary, is a democratically elected, representative body. It is a well-established principle of American democratic theory that the people have the right to be governed by substantive policies created by those whom they elect and whom they can replace. ${ }^{27}$

When Congress vests jurisdiction in the federal courts, it necessarily makes a decision inherently intertwined with substantive policy. ${ }^{28}$ By enacting jurisdictional statutes, Congress chooses a method to implement substantive legislative policy choices. ${ }^{29}$ For example, congressional policy choices concerning civil rights, environmental protection, and consumer guarantees require judicial action both to implement and protect those substantive rights. Thus, judicial implementation of jurisdictional directives is intertwined with the actual substantive policies being enforced. Indeed, as even Professor Friedman acknowledges, "the power to control jurisdiction undeniably encompasses the potential to control substantive rights." ${ }^{30}$ Principles of democratic theory and separation of powers require these jurisdictional policy decisions to be left to the majoritarian body of government: Congress. ${ }^{31}$

In contrast, the independent, unelected judiciary must not be permitted to usurp the democratic decision-making of Congress. The judiciary's role is simply to interpret and apply Congress's statutory grants of jurisdiction. Importantly, judicial interpretation of jurisdictional statutes is no less important than the judicial interpretation of any other statute. ${ }^{32}$ If the judiciary was permitted to disrupt Congress's jurisdictional grants, it would inevitably disrupt the judicial enforcement of the substantive policy Con-

26. See The Federalist No. 47 (James Madison).

27. See Martin H. Redish, Judge-Made Abstention and the Fashionable Art of "Democracy Bashing,” 40 CASE W. RsRv. L. Rev. 1023, 1027 (1989); Lawrence C. Marshall, "Let Congress Do It": The Case for an Absolute Rule of Statutory Stare Decisis, 88 Mich. L. Rev. 177, 201 (1989) ("It is the legislative branch which, to some degree or another, is answerable to the people, 'the only legitimate fountain of power.'" (footnote omitted) (quoting The Federalist No. 49, at 339 (James Madison) (J. Cooke ed 1961))); Wells, supra note 25, at 467 ("Since the members of Congress are elected by state and local constituencies, they are responsive to state and local concerns and provide a necessary check on the power of the unelected and tenured federal judiciary.").

28. Cf. Martin H. Redish, Abstention, Separation of Powers, and the Limits of the Judicial Function, 94 Y ALE L.J. 71, 112 (1984) ("The Supreme Court has recognized the important interrelations between congressional jurisdictional allocations and substantive congressional programs ...." (citing Testa v. Katt, 330 U.S. 386, 392-93 (1947))); Theodore Eisenberg, Congressional Authority to Restrict Lower Federal Court Jurisdiction, 83 Y ALE L.J. 498, 530 (1974) ("[T] he power to regulate jurisdiction[ ] is sometimes translatable into a power to regulate substantive rights.").

29. See Redish, supra note 28 , at $112-13$.

30. Friedman, supra note 5, at 60.

31. Cf. Redish, supra note 28 , at 77 ("If Congress intended that the federal courts exercise a particular jurisdiction, either to achieve substantive legislative ends or to provide a constitutionally-contemplated jurisdictional advantage, a court may not, absent constitutional objections, repeal those jurisdictional grants.").

32. Cf. Exxon Mobil Corp. v. Allapattah Servs., Inc., 545 U.S. 546, 558 (2005) (noting that "[o]rdinary principles of statutory construction apply" to "rules of federal jurisdiction”). 
gress sought to implement by providing jurisdiction. ${ }^{33}$ The judiciary cannot overrule Congress's policy decisions, absent constitutional concerns, merely because it disagrees. ${ }^{34}$ Indeed, federal courts' interpretation of jurisdictional statutes may be even more important than their interpretation of other statutes because in interpreting jurisdictional statutes, the courts determine the scope of their own authority. ${ }^{35}$ For that reason, a federal court must serve as a faithful agent, not a partner, in interpreting Congress's jurisdictional statutory directives. By adhering to the majordomo purposivist approach, courts will adhere to their discretionary yet limited role, always ultimately subservient to Congress, consistent with democratic theory and separation of powers principles.

\section{FEDERAL JURISDICTION, THE DIALOGIC APPROACH, AND THE PARTNERSHIP MODEL OF STATUTORY INTERPRETATION}

Despite the fact that the Constitution vests in Congress-and only Congress - the power to control federal courts' jurisdiction, a respected scholar has proposed an approach that provides federal courts a dramatically increased role in the process. A number of years ago, Professor Barry Friedman introduced the "dialogic" approach, which posits that Congress and the federal courts engage in a "dialogue" to develop jurisdictional policy. ${ }^{36}$ Under this theory, "the contours of federal jurisdiction are resolved as the result of an interactive process between Congress and the Court on the appropriate uses and bounds of the federal judicial power." 37 According to Professor Friedman,

The premise of the dialogic approach is that the constitutional text is broad enough to leave unresolved questions of how far Congress may go in controlling federal jurisdiction and, conversely, to what extent the federal courts may resist such control, or assert themselves in defining the scope of federal jurisdiction. ${ }^{38}$

33. See Redish, supra note 28 , at 77 (noting that when courts "modify[ ] [jurisdictional] legislation, [they] . . . alter[ ] a legislative scheme because of disagreement with the social policy choices that the scheme manifests").

34. Debra Lyn Bassett, Statutory Interpretation in the Context of Federal Jurisdiction, 76 Geo. Wash. L. Rev. 52, 56 (2007) ("The courts must accord the federal jurisdiction statutes the full import that the statutory language will support, while simultaneously assuring that the reach of such statues does not impermissibly extend beyond constitutional parameters.").

35. See id. at 53 ("[S]eparation-of-powers principles impose exceptional interpretive constraints on federal courts' constructions of their own judicial power."); Charles L. Black, Jr., The Presidency and Congress, 32 WAsh. \& LeE L. Rev. 841, 846 (1975) (arguing that "the rock on which rests the legitimacy of the judicial work in a democracy" is that federal courts only exercise jurisdiction when it is "on the basis of an Act of Congress"); Hessick, supra note 25, at 904 ("There is reason to think that careful adherence to congressional intent is more important in the interpretation of jurisdictional statutes than other statutes.").

36. Friedman, supra note 5, at 48.

37. Id. at $2-3$.

38. Id. at 48 . 
$\mathrm{He}$ argues that the dialogic approach allows jurisdictional issues to be decided "on a case-by-case basis through an elaborate dialogue between the branches." 39 The dialogue can be "cooperative, with one branch or the other seeking assistance in developing jurisdictional lines[,] . . educative, with one branch teaching the other where it believes appropriate lines ought to be drawn[,]" or on occasion, "more grave, like an elaborate game of 'push-shove.'" 40

The dialogic approach represents a classic example of a partnership model of statutory interpretation. The traditional judge-as-partner precept is based on the idea that while Congress has primary lawmaking authority, courts too have a lawmaking function, including when they interpret the statutory directives of Congress. ${ }^{41}$ Even where the directive and legislative purpose of a statute are apparent, a judge can "update" a statute where the judge believes that "changed circumstances have undermined original legislative assumptions, or . . . there have been inconsistent legislative signals over time, or in which new meta-policies supersede outdated policies." 42

The partnership interpretive model allows judges to construe what they may deem as Congress's functionally imperfect statutes and ensure that the statutes reflect the constitutional norms and public values of our nation. ${ }^{43}$ As for the authority of partnership judges to alter Congress's laws without a clear constitutional mandate, many partnership proponents advance the notion that the federal courts' employer is not Congress, but "the people" or "the United States" writ large. ${ }^{44}$ The key issue is that Congress often fails to explicitly supply interpretive norms along with its statutes, making statutory text "unintelligible without background norms

\section{Id. at 49 .}

40. Id.

41. See William N. Eskridge, Jr., Spinning Legislative Supremacy, 78 GEo. L.J. 319, 321-22 (1989). It is unclear whether Professor Friedman would even concede that Congress has the primary role in creating jurisdictional policy, describing federal jurisdiction decisions under the dialogic approach as a "shared responsibility." Friedman, supra note 5, at 52.

42. Eskridge, supra note 41, at 332; see also William D. Popkin, The Judicial Role: Statutory Interpretation and the Pragmatic Judicial Partner 4 (2013) (describing that the partner power of a judge in case or controversy allows the judge to consider "the contemporary policy significance of a decision (including systemic effects)").

43. See, e.g., William D. Popkin, The Collaborative Model of Statutory Interpretation, 61 S. CAL. L. Rev. 541, 585 (1988).

44. See, e.g., Daniel A. Farber, Statutory Interpretation and Legislative Supremacy, 78 Geo. L.J. 281, 284 (1989) (arguing that the employer of the federal courts "is not the Congress but [rather] the United States"); Jane S. Schacter, Metademocracy: The Changing Structure of Legitimacy in Statutory Interpretation, 108 HARv. L. REv. 593, 646-50 (1995) (arguing that judges have a "metademocratic" obligation to interpret statutes so as to produce "democratizing" effects); Paul W. Kahn \& Kiel Brennan-Marquez, Statutes and Democratic Self-Authorship, 56 WM. \& MARY L. REV. 115, 146-61 (2014) (arguing that common aspects of statutory interpretation reflect judges being faithful agents to "the people," not Congress). Partnership proponents fail to realize, however, that the judiciaryunlike Congress-is not in any way accountable to the populace. See supra notes 26-27 and accompanying text. 
that interpreters alone can supply." 45 Whereas a faithful agent court might produce an unsound result by seeking only the apparent purpose of the old statute, a partner court would be free to arrive at a sounder result by considering what a given statute "'ought to mean in terms of the needs and goals of our present day society." "46

Professor Friedman's partnership approach to federal jurisdiction must be rejected for three reasons. First, the Constitution unambiguously gives Congress the ability to create jurisdictional policy, and nothing in the Constitution permits the judiciary to ignore a statutory grant of jurisdiction. ${ }^{47}$ In other words, there is no constitutional basis for a dialogue between the legislature and the judiciary. Second, the dialogic approach runs counter to core principles of democratic theory and separation of powers. ${ }^{48}$ Finally, Professor Friedman's model does not describe an actual dialogue between Congress and the judiciary. ${ }^{49}$

\section{A. Absence of Constitutional Basis}

The Constitution provides a democratically accountable Congress with the means to make substantive policy decisions, including those involving questions of federal jurisdiction. Professor Friedman claims that because there exists a "textual basis for [both Congress and the judiciary] to assert primacy with regard to a particular jurisdictional dispute," the Constitution is "spacious enough to accommodate the dialogue." 50 To support this claim, Professor Friedman points to disagreement among commentators as to whether Congress has the power under Article III to limit and withdraw federal court jurisdiction. ${ }^{51}$ As Professor Friedman notes, some scholars suggest that Congress can restrict federal court jurisdiction because, based on the unambiguous language of Article III and the Madisonian Compromise, ${ }^{52}$ Congress is not required to create lower federal courts, and therefore, Congress also has the lesser power to restrict lower federal court jurisdiction or abolish federal court jurisdiction completely for certain subject matters. ${ }^{53}$ In contrast, other scholars argue that the text of Article III does not provide Congress as much power to restrict federal court jurisdiction; for example, one scholar points to the Article III language that judicial power "shall be vested" to argue that Congress's

45. Cass R. Sunstein, Interpreting Statutes in the Regulatory State, 103 Harv. L. REv. 405, 438 (1989).

46. William N. Eskridge, Jr., Dynamic Statutory Interpretation, 135 U. PA. L. Rev. 1479, 1480 (1987) (quoting Arthur W. Phelps, Factors Influencing Judges in Interpreting Statutes, 3 VAND. L. Rev. 456, 469 (1950)); see also Sunstein, supra note 45, at 439 (noting the need for interpreting judges to give "emphasis on particular settings").

47. See infra Section III.A.

48. See infra Section III.B.

49. See infra Section III.C.

50. Friedman, supra note 5 , at 50 .

51. Id. at 50-51.

52. See supra notes 13-20 and accompanying text.

53. Friedman, supra note 5, at 45. 
ability to limit federal jurisdiction is more restricted. ${ }^{54}$

Professor Friedman's argument is fundamentally and logically flawed for at least three reasons. First, to the extent there is ambiguity, that ambiguity is about whether Congress has the Article III power to limit federal court jurisdiction. The debate is not about whether federal courts have the constitutional authority under Article III to say "we disagree" with an act of Congress that grants federal courts jurisdiction and decline to exercise that jurisdictional grant. Thus, at most, Congress and the judiciary would have a "dialogue" about whether Congress could limit federal courts' jurisdiction.

Second, while Professor Friedman is correct that there is disagreement amongst scholars as to whether Congress can limit federal courts' jurisdiction, there is no doctrinal ambiguity. Indeed, the Supreme Court has consistently held that because Article III provides Congress the greater power to determine whether to create lower federal courts, it also provides Congress the lesser power to limit federal courts' jurisdiction. ${ }^{55}$

Finally, Professor Friedman premises the dialogic approach entirely on disagreement among scholars over the degree of congressional power over federal court jurisdiction. In his words, "The dialogic approach offers an interpretation of [A]rticle III that recognizes the inevitable fluctuation in views concerning congressional control and judicial resistance, and accommodates this fluctuation." 56 After Professors Amar and Wells - scholars on opposite sides of the congressional control debatecritiqued Professor Friedman's approach, ${ }^{57}$ all he could say in response was that Professors Amar and Wells "bec[a]me so mired in the very bog [he] had hoped to escape." 58 He reiterated his view that because "the Constitution's text . . . is spacious enough to support a number of positions," some of which are sharply conflicting, a dialogic approach is necessary. ${ }^{59}$

While Professor Friedman is correct that this debate exists, disagreement alone cannot justify an entirely new approach to interpreting the relative roles of Congress and the judiciary in defining federal jurisdiction. Instead, the supposed doctrinal ambiguity-if it actually existsmust be resolved. More importantly, Professor Friedman misses the key point: The scholarly debate focuses exclusively on congressional power to limit federal jurisdiction. That debate has no logical relevance to the issue at hand: the ability of Congress to vest jurisdiction in the federal courts, an issue over which-until Professor Friedman's work-there never ex-

54. Id. at 51; see Akhil Reed Amar, Taking Article III Seriously: A Reply to Professor Friedman, 85 Nw. U. L. REv. 442, 445 (1991). Justice Story also adopted this view. See Martin v. Hunter's Lessee, 14 U.S. (1 Wheat.) 304, 337-38 (1816).

55. See, e.g., Sheldon v. Sill, 49 U.S. (8 How.) 441, 448-49 (1850); Lockerty v. Phillips, 319 U.S. 182, 187 (1943); see also supra notes 21-24 and accompanying text.

56. Friedman, supra note 5, at 30.

57. See Amar, supra note 54; Wells, supra note 25.

58. Barry Friedman, Federal Jurisdiction and Legal Scholarship: A (Dialogic) Reply, 85 Nw. U. L. REV. 478, 478 (1991).

59. Id. 
isted scholarly debate. Finally, Professor Friedman fails to explain what text in Article III dictates that the judiciary and Congress should have a dialogue to determine the scope of federal jurisdiction. Indeed, no such text exists.

\section{B. The Dialogic Approach, Democratic Theory, and Separation of Powers}

The fundamental problem with the dialogic approach is its failure to adhere to traditional principles of democratic theory and separation of powers. Professor Friedman anticipates this critique but fails to dispel concerns. He argues, without explanation, that his approach is consistent with the Constitution, claiming that the constitutional plan is unclear as to whether "control of federal jurisdiction is vested in Congress." $60 \mathrm{He}$ therefore concludes that because "the sharing of power between Congress and Court is consistent with the constitutional plan, there is no separation of powers problem." 61 Professor Friedman's argument, however, merely begs the question by assuming the truth of the premise that the Constitution provides Congress and the Court shared power to create jurisdictional policy. The dialogic approach allows courts to usurp congressional power in violation of fundamental precepts of American democratic theory.

Principles of democratic theory mandate that the democratically elected Congress is responsible for creating substantive social policy. ${ }^{62}$ To be sure, federal courts have an absolute obligation to ensure that the democratically accountable branches enact laws within the bounds of the Constitution. ${ }^{63}$ But short of a finding of unconstitutionality, it is the responsibility of the legislative branch to create substantive policy, and that authority necessarily includes the power to shape federal jurisdiction in order to implement those policies. ${ }^{64}$ The judiciary has the power to interpret and apply those policies but may not ignore or overrule them unless the Constitution mandates otherwise. ${ }^{65}$ James Madison asserted that in our constitutional democracy, "judges can exercise no . . L Legislative

60. Friedman, supra note 5 , at 60 .

61. Id. at 59 .

62. See supra notes $26-35$ and accompanying text.

63. See Wells, supra note 25, at 467 (noting that in the context of Congress's control of federal jurisdiction, "Congress must respect other constitutional provisions" and may not, for example, "employ jurisdictional statutes to accomplish a deprivation of life, liberty, or property without due process of law").

64. Jurisdictional policy is intertwined with substantive policy, and separation of power concerns arise when the judiciary can alter or ignore Congress's jurisdictional grants. See supra notes 28-33 and accompanying text.

65. Redish, supra note 27, at 1027 ("American democracy is premised on what might be called the 'representational' principle, which posits that, within constitutionally established boundaries, the representative branches of government may make policy decisions, free from judicial power to ignore or overrule them simply on grounds of social, political or moral disagreement."); see also Tenn. Valley Auth. v. Hill, 437 U.S. 153, 194 (1978) ("While '[i]t is emphatically the province and duty of the judicial department to say what the law is,' it is equally - and emphatically - the exclusive province of the Congress not only to formulate legislative policies and mandate programs and projects, but also to establish their rela- 
function." 66 While in some sense this may be an overstatement, surely it is true in the face of enacted legislation. Professor Lawrence Marshall summarized this point effectively:

One of the central premises of the Constitution's division of powers, and the American system of government, is that the primary federal lawmaking authority belongs to Congress. If separation of powers means anything, it means that the task of creating law falls upon the legislature, and that courts must obey and enforce the constitutionally legitimate enactments of the legislative branch. ${ }^{67}$

Moreover, even the Court itself acknowledged its subordinate role to Congress with respect to its jurisdiction. ${ }^{68}$ Thus, any partnership model that removes from Congress the exclusive ability to create substantive jurisdictional policy must be rejected. ${ }^{69}$ But Professor Friedman has created a jurisdictional model that, in the guise of a dialogue, effectively enables federal courts to ignore unambiguous jurisdictional statutory directives.

Professor Friedman does not employ his dialogic approach solely to explain otherwise perplexing judicial doctrine. He also argues that from a normative perspective, the dialogic approach best serves principles of separation of powers. ${ }^{70} \mathrm{He}$ maintains that "the Court simply is more competent than Congress in refining jurisdictional decisions" because jurisdictional rules "must be painted with a narrower brush-and fine-tuned more frequently."71 But when Congress enacts a jurisdictional statute, it makes a policy decision that federal jurisdiction is appropriate in whatever particular circumstance it specifies. As a democratically elected body, Congress has an inherent and unique competence and legitimacy in shaping that jurisdictional policy. ${ }^{72}$

tive priority for the Nation." (citation omitted) (quoting Marbury v. Madison, 5 U.S. (1 Cranch) 137, 177 (1803))).

66. The Federalist No. 47, at 268 (James Madison) (E.H. Scott ed., Scott, Foresman \& Co. 1898); see also The Federalist No. 78, at 425, 428 (Alexander Hamilton) (noting that the while the legislature "prescribes the rules," the judiciary has "neither force nor will, but merely judgment" and cannot "substitute [its] own pleasure to the constitutional intentions of the Legislature").

67. Marshall, supra note 27, at 201.

68. Wells, supra note 25, at 468-69; see e.g., Patsy v. Bd. of Regents, 457 U.S. 496, 508 (1982) ("A judicially imposed exhaustion requirement would be inconsistent with Congress' decision to adopt $\S 1997$ e and would usurp policy judgments that Congress has reserved for itself.”); Owen Equip. \& Erection Co., v. Kroger, 437 U.S. 365, 372 (1978) ("[T] he jurisdiction of the federal courts is limited not only by the provisions of Art. III of the Constitution, but also by Acts of Congress.").

69. This does not mean, however, that courts are to play no creative role in implementing legislative judgments. See infra Section IV.C (discussing our proposed approach to statutory interpretation: majordomo purposivism).

70. Friedman, supra note 5, at 60 .

71. Id.

72. See James E. Pfander, Collateral Review of Remand Orders: Reasserting the Supervisory Role of the Supreme Court, 159 U. PA. L. REV. 493, 536 (2011) ("The federal courts, needless to say, lack the lawmaking competence and democratic legitimacy of Congress; a decision to exercise jurisdiction that Congress has apparently withheld poses obvious separation of powers issues."). 
By contrast, the federal judiciary is a countermajoritarian body; judges are appointed with life tenure and fixed salaries. ${ }^{73}$ They are therefore not accountable to the public's will in any meaningful way. Thus, they inherently lack the same democratic "competence" in the policymaking activity of defining the scope of federal jurisdiction. To the extent that jurisdictional rules often need to be "fine-tuned," the judiciary must always do so while adhering to Congress's goals in creating the grant of jurisdiction in the first place. Federal courts may use implementational discretion to best effectuate Congress's purposes but may not alter or ignore Congress's grant of jurisdiction based on its own policy preferences in the guise of a dialogue. ${ }^{74}$

Moreover, Professor Friedman argues that the dialogic approach fosters a more "sensible system of separation of powers" by sharing the responsibility of defining the scope of federal jurisdiction between Congress and the Court. ${ }^{75} \mathrm{He}$ argues that separation of powers principles are diminished by placing control of federal jurisdiction in the majoritarian body of government. ${ }^{76}$ But it is Congress that has the power to create substantive jurisdictional policy. Indeed, "[i]t has never been suggested ... that the judiciary may openly ignore a legislative judgment on any grounds other than unconstitutionality."77

\section{The Dialogue Myth}

Professor Friedman's dialogue is also flawed because it does not actually describe a true dialogue. First, Professor Friedman describes a sequence of independent actions by the legislature and judiciary, not an actual dialogue between the two branches of government. Second, Professor Friedman mistakenly asserts that Congress signals agreement, and thus participates in a dialogue, by means of acquiescence through silence. Third, Professor Friedman's dialogic model cannot possibly describe a true dialogue because, under his approach, the judiciary will always have the ultimate authority. Finally, any judicial claim to the existence of a dialogue is disingenuous because the judiciary has never acknowledged, and would never acknowledge, its participation in such a process.

\section{Sequence of Independent Actions, Not a Dialogue}

It remains unclear how Professor Friedman's dialogue is supposed to function in practice. The concept of a dialogue necessarily implies a sort of symbiotic process where two parties work and reason together to determine an answer to some question. Indeed, the dictionary definition of "dialogue" is "a conversation between two or more persons" involving "an exchange of ideas and opinions"; often this discussion is "aimed at

\footnotetext{
73. See U.S. ConsT. art. III, $\S 1$.

74. See infra Section IV.C.

75. Friedman, supra note 5, at 60 .

76. Id.

77. Redish, supra note 28 , at 76 .
} 
resolution" of some conflict. ${ }^{78}$ But Professor Friedman's approach does not describe this sort of dialogue. As Professor Tushnet noted, when Professor Friedman refers to a dialogue between the judiciary and the legislature, "he simply means a sequential process of interventions by one and then the other branch." ${ }^{\prime} 9$ Professor Friedman describes a process where "Congress does something, the Court responds by interpreting the statute or ignoring it, Congress responds to the Court's action by doing nothing or by enacting another statute, and so on until some equilibrium, lasting for an indefinite period, is reached." 80 This is not a dialogue; the branches are not communicating with each other but are instead acting separately and unilaterally. ${ }^{81}$ Indeed, even Professor Friedman recognized that the dialogic approach does not describe a true dialogue between Congress and the judiciary, acknowledging that at times the "dialogue" is really "an elaborate game of 'push-shove,' in which the branches resist one another's view of when the exercise of federal jurisdiction is appropriate." 82

There are, in contrast, examples of true dialogue in the legislative branch during the policymaking process. For example, members of the House of Representatives and the Senate participate in a dialogue during conference committee. Before sending a bill to the President, the House and Senate "must reach full and precise agreement on its text." 83 To resolve differences between the House and Senate versions, the houses create a "conference committee." ${ }^{84}$ Based on House rules, "all matters in disagreement are open to discussion at a conference meeting." 85 The conferences are "negotiating forums," where the conferees from both houses work together to determine the final language of a bill. ${ }^{86}$ At a conference committee, the representatives from the Senate and the House have a true dialogue. Ultimately, no party has the final say, as the conferees must reach an agreement and present a conference report detailing how they resolved each disagreement discussed. ${ }^{87}$ By contrast, the dialogue Professor Friedman describes does not involve direct communication between parties and gives a single party-the Court-final authority.

\section{Fallacy of the Assumption of Congressional Silence as Acquiescence}

Professor Friedman's dialogue suffers from a second flaw: he contends

78. Dialogue, Merriam-Webster, http://www.merriam-webster.com/dictionary/dialogue [https://perma.cc/S2C4-NYUV].

79. Mark V. Tushnet, The Law, Politics, and Theory of Federal Courts: A Comment, 85 Nw. U. L. ReV. 454, 454 (1991).

80. Id. at $454-55$.

81. See id. at 455 (stating that a "dialogue" requires "some interaction, in the sense that each participant considers seriously the significance of the preceding intervention by the other participant").

82. Friedman, supra note 5 , at 49.

83. Elizabeth Rybicki, Cong. Rsch. Serv., 96-708, Conference Committee And Related Procedures: An Introduction 1 (2015).

84. Id. at 2 .

85. Id. at 5 .

86. Id. at 6 .

87. Id. at 7. 
that Congress participates in the dialogue through silent acquiescence. ${ }^{88}$ This argument assumes that Congress would legislatively act to counter a court's jurisdictional decision if it disagreed, and therefore, Congress's failure to act, "combined with reenactment of the relevant substantive and jurisdictional legislation," results in Congress's implicit acceptance and ratification of the Court's decisions. ${ }^{89}$

This is not a dialogue but rather the absence of dialogue. Professor Friedman's argument improperly treats the failure to legislate as the legal equivalent of enacting legislation. But the Constitution mandates that when Congress enacts policy into law, that legislation must advance through an extensive legislative procedure, including "a detailed and rigorous substantive inquiry, investigation, debate, and formal review in both houses of Congress." 90 When Congress remains silent, it of course performs none of those tasks. Thus, congressional silence cannot amount to tacit endorsement of judicially adopted jurisdictional policy. ${ }^{91}$ Professor Friedman himself acknowledges that congressional silence is necessarily plagued with ambiguity concerning Congress's intentions. ${ }^{92}$

\section{A Rigged Dialogue: Making the Court the Ultimate Authority}

In describing his concept of the dialogue, Professor Friedman contends that neither Congress nor the judiciary has ultimate authority. ${ }^{93}$ There are multiple concerns with this line of reasoning. Most notably, there is no question that according to basic principles of separation of powers, Congress has the first and last word in passing legislation regarding substantive policy, including jurisdictional policy. ${ }^{94}$

Professor Friedman asserts that "[u]nder the dialogic approach . . . should there be a dispute between branches, politics will determine which branch prevails." 95 It is not at all clear what he means by this statement. It is possible he means there will be some sort of political pressure placed on the judiciary to follow Congress's directive. But the federal judiciary was carefully designed so as not to be susceptible to political pressure. ${ }^{96}$ Perhaps he means the public will pressure Congress to act to counter the judiciary through political participation. However, this does not seem like a realistic possibility. The public is generally unconcerned with esoteric and arcane questions of jurisdiction. Thus, politics cannot be the final ar-

88. Friedman, supra note 5 , at 59 .

89. See Redish, supra note 28 , at 81 .

90. Id. at 82 .

91. Id.

92. Friedman, supra note 5 , at 59.

93. Id. at 54-55.

94. See supra Sections III.A, III.B.

95. Friedman, supra note 5, at 54-55.

96. See Neil Kinkopf, Executive Privilege: The Clinton Administration in the Courts, 8 WM. \& MARY BILl RTS. J. 631, 646 (2000) ("The judicial branch is designed to be insulated from politics in order 'to secure a steady, upright, and impartial administration of the laws." (quoting The Federalist No. 78, at 465 (Alexander Hamilton) (Clinton Rossiter ed., 1961)). 
biter of a dispute between Congress and the judiciary regarding jurisdictional policy.

In any event, even if Congress did desire to respond to the judiciary, as a practical matter, it has no ability to participate effectively in the dialogue. Partnership proponents cannot point to any check in the Constitution restricting the judicial branch's ability to usurp legislative authority. Under the dialogic approach, the judiciary always has the final say.

Imagine, for example, that Congress starts a "dialogue" regarding the diversity jurisdiction statute, deciding to expand federal jurisdiction for diversity cases by reducing the statutory minimum from $\$ 75,000$ to $\$ 50,000$. A federal court believes that such an expansion is improper and participates in a dialogue by declining to exercise jurisdiction in cases concerning less than $\$ 75,000$, despite the congressional directive. Unsurprisingly, Congress is unhappy with the court for ignoring its directive and wants to participate in a dialogue to express its displeasure. The critical question Professor Friedman is unable to answer is how Congress can do so. Congress already enacted a statute that the federal judiciary disregarded. Congress is unlikely to remove federal judges or lower their salaries in such a situation. Thus, the only conceivable way Congress can respond to the judiciary is to pass the same jurisdictional statute a second time. To require Congress to pass the same substantive policy twice, however, is contrary to the requirements of Article I and, in any event, extremely inefficient.

Requiring Congress to pass a substantive policy twice for a federal court to enforce that policy is contrary to the Constitution. For Congress to create substantive policy, Article I of the Constitution requires bicameral "passage by a majority of both Houses and presentment to the President." 97 Article I does not require bills to be enacted twice before they become law.

Moreover, the legislative process is plagued by an institutional political inertia that Congress must overcome. Thousands of bills are introduced during each session of Congress, and only a few are enacted into law. ${ }^{98}$ For those bills that do become law, the process is arduous and time-consuming. ${ }^{99}$ It is extremely unlikely that Congress could successfully enact a jurisdictional statute a second time to override a federal court (or, as Professor Friedman would say, to have a "dialogue" with the court). ${ }^{100}$ And even if Congress did pass a law a second time, there is nothing to stop a federal court from ignoring the law once again. In the guise of a dialogue,

97. INS v. Chadha, 462 U.S. 919, 958 (1983).

98. Martin H. Redish \& Shane V. Nugent, The Dormant Commerce Clause and the Constitutional Balance of Federalism, 1987 Duke L.J. 569, 592.

99. See generally Roger H. Davidson \& Walter J. Oleszek, Congress and Its Members 264, 263-85 (2d ed. 1985) (noting in the chapter on "Congressional Rules and Procedures" that "[t]here is little to prevent obstruction at every turn" in the lawmaking process).

100. See Thomas W. Merrill, The Common Law Powers of Federal Courts, 52 U. CHI. L. Rev. 1, 22-23 (1985). 
a federal court could, as it did before, simply refuse to enforce Congress's jurisdictional policy. ${ }^{101}$

\section{A Disingenuous Dialogue}

Finally, it should be noted that the judiciary has never acknowledged, and would never acknowledge, having a dialogue with Congress about federal jurisdiction. The judiciary is well aware that it lacks any constitutional authority to participate in any sort of dialogue with Congress; acknowledgment of a dialogue would force courts to acknowledge their usurpation of Congress's Article I authority. Instead, the judiciary effectively disguises its usurpation of congressional authority in the form of statutory interpretation. ${ }^{102}$

A court participating in a true dialogue would presumably say: "We know that you prefer we exercise jurisdiction because the amount in controversy here is greater than the new statutory minimum. ${ }^{103}$ But that is a bad idea, and therefore, we decline to exercise jurisdiction. Please increase the jurisdictional minimum." Of course, a federal court would never make this sort of request. Instead, to the extent the courts actually believe they are a participant in a Friedmanesque dialogue, the judiciary disguises its actions as statutory interpretation.

\section{THE THEORY OF STATUTORY INTERPRETATION AS INTERPRETATION: THE JUDGE AS A FAITHFUL AGENT}

Rather than acting as Congress's "partner" by participating in a mythical "dialogue" with Congress, the judiciary's appropriate role in interpreting and applying federal jurisdiction statutes is to serve as Congress's faithful agent. The faithful agent conception of courts in interpreting statutes is best explained as flowing logically from an understanding of the basic premises of our political order. ${ }^{104}$ Our constitutional democracy separates the legislative and the judicial powers, supplying an electorally

101. This judicial usurpation of congressional power in the guise of a dialogue, we should emphasize, differs from instances where courts use "resistance norms" to construe congressional statutes restricting federal jurisdiction narrowly in order to avoid potential constitutional questions. See Ernest A. Young, Constitutional Avoidance, Resistance Norms, and the Preservation of Judicial Review, 78 Tex. L. Rev. 1549, 1551 (2000). The Court employs resistance norms to avoid constitutional concerns that would arise if Congress statutorily precluded judicial review of constitutional claims. For example, the AntiTerrorism and Effective Death Penalty Act of 1996 (AEDPA) seemed to deprive the Court of appellate jurisdiction based on its plain statutory language. Id. at 1554. Nevertheless, the Court interpreted the AEDPA narrowly, and thus "avoided any "plausible argument that the [AEDPA] has deprived [the] Court of appellate jurisdiction in violation of Article III, section 2.'” Id. at 1561 (quoting Felker v. Turpin, 518 U.S. 651, 662 (1996)).

102. See infra Part IV.

103. Since this is a "dialogue," presumably the judiciary would be "conversing" directly with Congress and would therefore use the second person.

104. Martin H. Redish \& Theodore T. Chung, Democratic Theory and the Legislative Process: Mourning the Death of Originalism in Statutory Interpretation, 68 Tul. L. Rev. 803, 811 (1994). 
accountable legislature with express authority to make jurisdictional policy, and an appointed, tenured, and electorally unaccountable federal judiciary with no express policy-making authority other than that required by the Constitution. ${ }^{105}$ It follows that the federal judiciary should not have the independent power to alter the constitutionally valid jurisdictional policy decisions of Congress. ${ }^{106}$ A different understanding of the relationship between Congress and the federal courts interpreting Congress's statutes undermines the concepts of self-determination and popular sovereignty that are at the core of our system. ${ }^{107}$

Two theories of statutory interpretation seek to adhere to the faithful agent precept: textualism and purposivism. A review of the two methods suggests that neither-at least, absent modification-provides a satisfactory answer. The contemporary textualist method often leads judges to burden Congress impermissibly in making its purpose clear. It also cuts short the necessary holistic analysis involved in assessing legislative text for the purposes behind Congress's directives. Modern purposivism steers towards a rule-based analysis that fails to adequately account for the implementational discretion that an interpreting judge must exercise to best effectuate congressional goals. Instead, we here introduce an alternative version of the faithful agent model-what we call majordomo purposivism. Before we detail the contours of this approach, we first discuss the flaws in the theories of textualism and purposivism.

\section{A. Textualism}

At the center of textualism is the assumption that "most interpretive questions have a right answer" that can be reached through assessing only the semantic meaning of statutory text. ${ }^{108}$ Textualists focus on the Constitution's bicameralism and presentment requirements, which prescribe the process for making law: that the text of any statute is approved by both houses of Congress and the President. ${ }^{109}$ Accordingly, textualists disregard nontextual sources that did not pass through bicameralism and presentment. ${ }^{110}$ Instead, textualists contend that federal judges have a duty to enforce only duly enacted text-which they view as "the currency of legislative compromise." 111 Straying from the semantic meaning of statutory text risks disturbing the "unknowable" deal made into law through

105. See Sunstein, supra note 45 , at $434-35$ (describing underpinnings of the faithful agent conception).

106. See Martin H. Redish, The Federal Courts in the Political Order: Judicial Jurisdiction and American Political Theory 36-42 (1991).

107. Redish \& Chung, supra note 104 , at 811.

108. Antonin Scalia \& Bryan A. Garner, Reading Law: The Interpretation of Legal Texts 6 (2012).

109. See U.S. Const. art. I, § 7, cl. 2.

110. John F. Manning, Second-Generation Textualism, 98 CALIF. L. Rev. 1287, 1314 (2010) [hereinafter Manning, Second-Generation Textualism]; see also John F. Manning, What Divides Textualists from Purposivists?, 106 Colum. L. REv. 70, 91-95 (2006) [hereinafter Manning, What Divides Textualists from Purposivists?].

111. Manning, What Divides Textualists from Purposivists?, supra note 110, at 99. 
the bicameralism and presentment process. ${ }^{112}$

Textualists concede that it is often necessary to discern the meaning of text by reference to judicially crafted canons of statutory construction. ${ }^{113}$ Textualists justify the use of these canons as the most dependable means of arriving at the semantic meaning of statutory text, thereby respecting legislative compromise and adhering to the faithful agent conception. ${ }^{114}$ Textualists distinguish the canons from other nontextual sources such as legislative history, based on their "venerable" status and the purpose they serve to "promote clearer drafting" by Congress. ${ }^{115}$

While textualists are correct both to emphasize the importance of bicameralism and presentment and to assert that statutory text and context are at the center of any judicial interpretation of a congressional directive, textualism ultimately violates the faithful agent precept by conducting an unduly and artificially narrow form of interpretation. Textualism terminates a faithful agent analysis as soon as the semantic meaning of the text fails to directly address the interpretive question before the court. In purporting to adhere to the text in the name of legislative supremacy, textualists undermine their very purpose-they cut off the attempt to discern Congress's policy decisions and instead insert judge-made rules for reading text. Textualism therefore misses the forest of the faithful agent precept for the trees of the formalism of the legislative process.

\section{B. Purposivism}

Unlike textualism, purposivism permits the judiciary to look beyond statutory text. A purposivist judge locates and gives effect to the purposes behind congressional statutes, assuming that each statute has at least one definitive purpose and that the Congress enacting the statute was made up of "reasonable persons pursuing reasonable purposes reasonably." 116 To locate a statute's purpose, the purposivist approach permits a judge to consider a variety of legislative sources, including statutory text, legislative history, and broader inquiries into the landscape of the law.117 Purposivist thinking today emphasizes that statutory interpretation

112. Manning, Second-Generation Textualism, supra note 110, at 1304.

113. John F. Manning, Textualism and the Equity of the Statute, 101 Colum. L. Rev. 1, 71-73, 95-96 (2001).

114. See generally SCALIA \& GARNER, supra note 108, at 69-339 (discussing the canons of construction); see also Manning, What Divides Textualists from Purposivists?, supra note 110 , at 110 .

115. See Scalia \& Garner, supra note 108, at 51; see also John F. Manning, What Divides Textualists from Purposivists?, supra note 110, at 82 ("Textualists also rely on offthe-rack canons of construction peculiar to the legal community, including some substantive (policy-oriented) canons that have come to be accepted as background assumptions by virtue of longstanding prescription.").

116. See Henry M. Hart, Jr. \& Albert M. Sacks, The Legal Process: Basic Problems in the Making and Application of Law 1378 (William N. Eskridge, Jr. \& Philip P. Frickey eds., 1994).

117. See id. at 1379-80. 
should give primacy to statutory text. ${ }^{118}$ At the same time, purposivists adhere to particularized rules when considering sources beyond the text in order to counter concerns about extratextual sources. ${ }^{119}$

Several modern commentators have attempted to reframe the very aim of purposivist analysis. Professor Nourse, for example, argues that the target of purposivist analysis should be to arrive at interpretations that effectively convey Congress's purpose to the public, which can be determined by utilizing a set of principles to interpret text and legislative history. ${ }^{120}$ Likewise, Professor Elhauge has argued for a set of "statutory default rules" meant to give judges a uniform process for resolving statutory ambiguity and discerning what he calls the preferences of the enacting legislature. ${ }^{121}$

Purposivists accurately recognize the judge's obligation to conduct a broader inquiry when interpreting a statute, while acknowledging textualists' valid bicameralism and presentment concerns. Yet their turn towards a more textualist, rule-based approach risks going in the wrong direction. Purposivists risk losing sight of the fact that judges often make tough calls when the specific purposes of Congress cannot be reliably discerned from statutory text. In addition, modern purposivists underplay the need for judges to exercise some limited form of implementational discretion (at least to the extent allowed by text) once they have identified pertinent congressional purposes. ${ }^{122}$

Recognition of the importance of limited judicial discretion in the act of interpreting ambiguous text is not an invitation to stray from core purposivist principles. Instead, a purposivist judge can only rest assured when she is confident that she has discerned relevant purposes, and then

118. See Jonathan T. Molot, The Rise and Fall of Textualism, 106 Colum. L. Rev. 1, 30-36 (2006). Professor Molot himself advocates for a "moderate" form of textualism that "balance[s] textualist and purposivist impulses consistently across cases." Id. at 65. For all intents and purposes, it seems fair to call this a moderated version of purposivism. See also Jonathan R. Siegel, The Inexorable Radicalization of Textualism, 158 U. PA. L. REv. 117, 175-78 (discussing how purposivism and intentionalism can adjust to "textualist lessons").

119. Judge Katzmann, for example, has written extensively in recent years to promote and defend a purposivist approach that starts with text and uses a principled approach to discern congressional purpose from nontextual sources. Robert A. KATZMAnN, Judging Statutes 29-54 (2014); Robert A. Katzmann, Statutes, 87 N.Y.U. L. Rev. 637, 667-70 (2012). Judge Katzmann also suggests there is room for political actors to take steps that would make the purposivist approach more sound, including congressional promulgation of drafting checklists, default interpretive rules, or an "official listing" of legislative history. See Katzmann, Judging Statutes, supra, at 92-104.

120. Victoria Nourse, Misunderstanding Congress: Statutory Interpretation, the Supermajoritarian Difficulty, and the Separation of Powers, 99 Geo. L.J. 1119, 1152, 1174-77 (2011). Professor Nourse purports to reject purposivism in favor of a type of "ordinary meaning textualism" that utilizes legislative history. See id. at 1175. Despite the "textualism" descriptor, we take Professor Nourse as working generally under the umbrella of purposivism.

121. Einer Elhauge, Statutory Default Rules: How to Interpret Unclear LEGISLATION 9 (2008). The novel twist of Elhauge's purposivism is that courts can best approximate the preferences of the enacting legislature by looking for "official actions" of the current legislature that signal its preferences on the question. See id. at 41-43, 64-65 (suggesting recent statutes and official agency actions would count as "official").

122. See infra Section IV.C. 
worked within those purposes to reach an interpretive outcome giving the greatest possible effect to the relevant congressional purposes involved. This task requires fully explaining what it means for a judge to be a faithful agent in our constitutional scheme. Given that partnership methodologies clearly contravene the faithful agent precept, and neither contemporary textualism nor purposivism squarely accounts for the role of judicial discretion, we think a reconception, or perhaps a modern restatement, of the role of faithful agent judges in interpreting statutes is necessary.

\section{The Majordomo Conception of Purposivism}

We introduce "majordomo purposivism" not as a radically new form of statutory interpretation or as a method that can "solve" the hardest cases. ${ }^{123}$ Instead, the goal of introducing this precept is to reemphasize and concisely describe a judge's role, and, at least, the initial process of interpreting statutes as a faithful agent of Congress. This means respecting bicameralism and presentment concerns and giving the statute's text primacy, while simultaneously recognizing that where a statute's language is imprecise, courts must look to surrounding context and common sense to discern the statute's broader purposes. The scheme of our constitutional democracy does allow the courts to exercise a limited form of what we call "implementational discretion" in determining how best to protect and give the most effect to the purposes Congress expresses through its statutes. At the same time, a majordomo purposivist judge must avoid the temptation to use implementational discretion to justify partnership-like conceptions of judging and be mindful not to impose judge-made policy preferences upon Congress.

We use the term "majordomo" because it effectively describes the limited discretionary, yet subordinate, roles of the federal judge in relation to Congress's enactment of constitutionally valid statutes. A majordomo can be defined as "the head steward or butler in the household of a sovereign or great noble." 124 Use of the term emphasizes that the "standing charge" of the courts is to protect and effectuate the directives that come from Congress over time.

We take as inevitable the possibility that Congress's directives will occasionally be imprecise or unclear. A majordomo purposivist does not view this as an opportunity to stray from notions of legislative supremacy or employ self-made rules for determining outcomes. While partnership models permit the judiciary to consider what it perceives as the goals, values, and social norms of society-without due regard to congressional motivation ${ }^{125}$ - the majordomo purposivist approach recognizes that the judiciary is, above all else, subservient to Congress in interpreting its stat-

123. See Lawrence C. Marshall, The Canons of Statutory Construction and Judicial Constraints: A Response to Macey and Miller, 45 VAND. L. Rev. 673, 674-75 (1992).

124. Majordomo, American Heritage Dictionary, supra note 11.

125. See supra notes $41-46$ and accompanying text. 
utes. Thus, majordomo purposivist judges exercise a limited form of implementational discretion to arrive at interpretations they honestly believe best protect, and give the most effect to, the pertinent purposes at play behind the congressional directives.

Majordomo purposivist judges, unlike partnership model advocates, cannot exercise their implementational discretion to question, refresh, or otherwise jump at opportunities to revisit the wisdom of Congress's pertinent jurisdictional policy decisions. Perhaps the clearest example of the difference between a partnership model judge and the majordomo purposivist judge is presented in William Eskridge's "relational agent" hypothetical, in which the principal, Williams (i.e., Congress) has a detailed contractual arrangement with an agent, Diamond (i.e., the lower courts) to oversee the preparation of meals for her family. ${ }^{126}$ In one scenario, Williams reads a "Wellness Letter" regarding cholesterol levels before leaving for a long trip and changes Diamond's meal preparation instructions to include a type of bran muffin and fresh apples reported by the Wellness Letter to prevent future cholesterol problems later in life.127 In what Eskridge describes as the actions of a "faithful relational agent," after Williams departs Diamond continues to read the Wellness Letter, as well as other cholesterol literature, and thereafter implements on an ongoing basis significant changes to the family's meals in order to further lower the family's cholesterol intake. ${ }^{128}$ To Eskridge, this is a laudable example of a faithful agent updating the principal's directives based on current information and norms that the principal presumably is not able to routinely update herself (but would if she could).

In our view, this relational agent precept improperly fails to require the agent to thoughtfully reverse-engineer the principal's intent, in favor of empowering the agent to make short-hand assumptions about the principal's directives based on new information and norms. Just because the principal Williams changed her meal instructions once to address cholesterol concerns based upon a periodical, the agent Diamond is not now somehow authorized to (1) continually reference new issues of that periodical on an on-going basis to update Williams's directive under the assumption that because Williams referenced the periodical once, the periodical has somehow been anointed as a fountain of new authority for Diamond to modify Williams's directives moving forward; (2) read other authority about cholesterol under the assumption that Williams would have read it and acted upon it if she could have; and (3) implement changes in Williams's directive at all opportunities to further reduce cholesterol intake under the assumption that one directive to balance a diet to address cholesterol grants Diamond authority to further reduce cholesterol intake. Each of these are examples of the agent jumping to usurp the principal's discretion based on what seems right to the agent in the

126. See Eskridge, supra note 41, at 327-30.

127. Id. at 328-29.

128. Id. at 328 . 
moment rather than first carefully attempting to determine the principal's intent in light not just of the narrow specifics of the order in question, but of the much broader context of the principal's array of directives to the agent.

Put simply, institutionalist principles of democratic theory make clear that questions of federal jurisdictional policy-short of issues of constitutionality-are for the representative and accountable legislature to decide. In contrast, it is the job of the judiciary, a nonrepresentative body, to implement that policy based on the legislature's policy choice. ${ }^{129} \mathrm{Fi}$ nally, unlike Professor Eskridge's approach, majordomo purposivism never allows an interpreting court to ignore unambiguous text. The majordomo approach ensures that the judiciary does not usurp legislative authority by defining its own jurisdiction; however, it still authorizes federal courts - within the limitations imposed by unambiguous legislative text - to use their best judgment to determine congressional purpose and to employ implementational discretion that best effectuates Congress's desires when determining the scope of federal jurisdiction.

At the core of majordomo purposivism is the assumption that any given statutory provision has at least one discernible "point A to point B" purpose. The first place the majordomo judge discerns this purpose is the operative text of the statute. When the statutory text provides the court with an unambiguous directive, a majordomo judge must effectuate Congress's unambiguous statutory instructions. But often the text of a statute is unclear. In such a situation, a majordomo must look beyond the text of the statute in order to reverse-engineer Congress's purpose, and then employ implementational discretion to interpret the statute in a way that best effectuates that purpose.

A majordomo purposivist need not follow any sort of magic formula in determining purpose, but this reverse-engineering analysis is similar to what Judge Posner--in what we consider to be a purposivist spirit--once called "imaginative reconstruction." 130 Through imaginative reconstruction, a judge considers not only "the language and apparent purpose of the statute, its background and structure, its legislative history . . ., and the bearing of related statues," but also "values and attitudes, so far as they are known today, of the period in which the legislation was enacted."131 A majordomo purposivist "should try to think his way as best

129. See supra notes $26-35$ and accompanying text.

130. Richard A. Posner, The Federal Courts: Crisis and Reform 287 (1985) [hereinafter Posner, CRISIS AND REFORM]; see also Richard A. Posner, Statutory Interpretation -In the Classroom and in the Courtroom, 50 U. CHI. L. Rev. 800, 817 (1983) [hereinafter Posner, Statutory Interpretation]. Judge Posner has since reconceptualized the task of interpreting statutes in a manner we think strays into the partnership conception of judging. See Richard A. Posner, Law, Pragmatism, and Democracy 59-64 (2003); see also John F. Manning, Statutory Pragmatism and Constitutional Structure, 120 Harv. L. REv. 1161, 1168-69 (2007) (discussing Posner's statutory interpretation as judge).

131. Posner, Statutory Interpretation, supra note 130, at 818; see also POSNER, CRISIS AND REFORM, supra note 130, at 287. Judge Learned Hand also advocated for this sort of statutory analysis. See, e.g., United States v. Klinger, 199 F.2d 645, 648 (2d Cir. 1952), aff'd 
he can into the minds of the enacting legislators and imagine how they would have wanted the statute applied to the case at bar."132 Thus, a majordomo purposivist judge should "decide what attribution of meaning to the statute will yield the most reasonable result . . . always bearing in mind . . . that it is [the legislators'] conception of reasonableness, to the extent known, rather than the judge's, that should guide decision." 133

The majordomo inquiry is, paradoxically, both broad and constrained. It is broad in the sense that the judge should search text, context, and-at least occasionally-legislative history in order to discern Congress's purpose. It is constrained, however, in the sense that judges are not free to insert judicial policy or judge-made rules of interpretation into their analysis. Instead, the majordomo purposivist must work only within those congressional purposes identified to arrive at an interpretive outcome.

As Professor Max Radin long ago pointed out, almost any interpretive process can become an avenue for judicially created policy. ${ }^{134}$ But merely because the process of identifying clear purposes, and implications of those purposes, involves a slippery slope, it should not be considered fatal to the interpretive process. As Judge Posner aptly put it, "the irresponsible judge will twist any approach to yield the outcomes that he desires and the stupid judge will do the same thing unconsciously." 135 The risk of judicial usurpation of legislative authority is pervasive throughout all methodologies of statutory interpretation. Ultimately, however, a judge must exercise some limited discretion, though we seek to constrain this discretion by describing it as "implementational." In this sense, the judge's discretion is strikingly similar to that of a real-life majordomo: determining how best to implement the broad goals of those possessing full decision-making power in particular situations. We believe the process of directing judges to reverse-engineer Congress's purpose, and then use their implementational discretion to reach an interpretation that best effectuates that purpose, most closely adheres to the faithful agent precept and thus the democratic values which lie at the heart of American political theory.

\section{APPLYING MAJORDOMO PURPOSIVISM TO FEDERAL JURISDICTION STATUTES}

Majordomo purposivism provides a framework of statutory interpretation for courts to employ in interpreting congressional statutes. It ensures

per curiam, 345 U.S. 939 (1953) ("When we ask what Congress 'intended,' usually there can be no answer, if what we mean is what any person or group of persons actually had in mind. Flinch as we may, what we do, and must do, is to project ourselves, as best we can, into the position of those who uttered the words, and to impute to them how they would have dealt with the concrete occasion.").

132. Posner, Statutory Interpretation, supra note 130, at 817; see also PosNER, CRISIS AND REFORM, supra note 130, at 286-87.

133. Posner, Crisis ANd Reform, supra note 130, at 287.

134. Max Radin, Statutory Interpretation, 43 Harv. L. Rev. 863, 876-78 (1930).

135. Posner, Statutory Interpretation, supra note 130, at 817. 
that the judiciary serves its proper role as Congress's faithful agent, effectuating the policy decisions made by the majoritarian branch. In this Part, we apply majordomo purposivism to examine the Court's federal question jurisdiction and diversity jurisdiction doctrines. The text of both statutes is unclear on at least some points, so we begin-as a majordomo purposivist judge would-by examining the context surrounding the enactment of those statutes with the aim of reverse-engineering the congressional purposes. With those purposes in mind, we explore the Court's current jurisdictional doctrine and find that, in determining the scope of the jurisdictional statutes, the Court has often ignored congressional purpose, instead usurping legislative authority by creating jurisdictional rules based on judge-determined preferences.

\section{A. Federal Question Jurisdiction}

Under 28 U.S.C. $§ 1331$, Congress granted federal district courts "original jurisdiction of all civil actions arising under the Constitution, laws, or treaties of the United States." 136 A majordomo purposivist's goal in interpreting $\S 1331$, as it is when interpreting any statute, is to best adhere to Congress's wishes. First, the judiciary will look to the text of the statute. But because the words "arising under" are not self-defining, the text of the statute does not provide the judiciary clear instructions as to the scope of federal question jurisdiction. Thus, under a majordomo purposivist approach, the judiciary has discretionary authority beyond Congress's words and must look beyond the text of $\S 1331$. It must attempt to reverse-engineer Congress's purpose in enacting § 1331 and consider why Congress decided to enact a grant of general federal question jurisdiction. Then, while always remembering that their goal as faithful agents is to reflect Congress's wishes, majordomo judges use implementational discretion to arrive at an interpretation of $\S 1331$ that they believe best effectuates Congress's goals.

Based on the historical context surrounding the enactment of $\S 1331$, it is reasonable to conclude that Congress wished to allow litigants to have issues of federal law adjudicated in federal court, where they could benefit from the expertise and quality of the federal judiciary. Section 1331 was originally enacted by Congress as part of the Judiciary Act of 1875.137 The 1875 Act was one of several jurisdictional acts passed in the wake of the Civil War due to a congressional lack of trust in state courts. ${ }^{138}$ Just four years earlier, Congress enacted the Civil Rights Act of 1871 due to "[a] pervasive sense of nationalism" in order to "empower[] the lower federal courts" to protect rights guaranteed by the Constitution and federal law. ${ }^{139}$ Congress recognized that "state courts were being used to

136. 28 U.S.C. $\S 1331$.

137. Judiciary Act of 1875 , ch. $137, \S 1,18$ Stat. 470 (codified as amended at 28 U.S.C. $\S \S 1331-1332)$.

138. Hessick, supra note 25 , at 908.

139. Steffel v. Thompson, 415 U.S. 452, 463-64 (1974). 
harass and injure individuals."140 Thus, it recognized the need for stronger federal courts. As Senator Thomas Osborn stated:

If the State courts had proven themselves competent to suppress the local disorders, or to maintain law and order, we should not have been called upon to legislate .... We are driven by existing facts to provide for the several States in the South what they have been unable fully to provide for themselves; i.e., the full and complete administration of justice in the courts. And the courts with reference to which we legislate must be the United States courts. ${ }^{141}$

Similarly, Representative John Coburn recognized that federal courts provide a better brand of justice. He stated:

The United States courts are further above mere local influence than the county courts; their judges can act with more independence, cannot be put under terror, as local judges can; their sympathies are not so nearly identified with those of the vicinage; the jurors are taken from the State, and not the neighborhood; they will be able to rise above prejudices or bad passions or terror more easily. ${ }^{142}$

Thus, as the Court has recognized, the "legislative history makes evident that Congress clearly conceived that it was altering the relationship between the States and the Nation with respect to the protection of federally created rights." 143

Though there exists minimal legislative history surrounding the 1875 Act itself, the little that does exist and the circumstances surrounding the Act's enactment make clear that the Act was motivated by the same distrust of state courts following the Civil War that motivated the Civil Rights Act of 1871. Congress did not trust state courts to vindicate federal rights and passed the 1875 Act in order to provide individual litigants a federal forum to adjudicate their federal and constitutional rights. ${ }^{144}$ As the Court stated, after the Civil War, "nationalism dominated political thought and brought with it congressional investiture of the federal judiciary with enormously increased powers. The Act of March 3, 1875, was the principal 'measure of the broadening federal domain in the area of individual rights." 145 Justice Brennan noted this historical context in his dissenting opinion in Merrell Dow Pharmaceuticals Inc. v. Thompson, stating that one "reason Congress conferred original federal-question jurisdiction on the district courts was its belief that state courts are hostile

140. Mitchum v. Foster, 407 U.S. 225, 240 (1972).

141. Cong. Globe, 42d Cong., 1st Sess. 653 (1871).

142. Id. at 460 .

143. Mitchum, 407 U.S. at 242.

144. See Hessick, supra note 25, at 908; Patti Alleva, Prerogative Lost: The Trouble with Statutory Federal Question Doctrine After Merrell Dow, 52 OHio ST. L.J. 1477, 1497-98 (1991); G. Merle Bergman, Reappraisal of Federal Question Jurisdiction, 46 MicH. L. Rev. 17, 28 (1947).

145. Zwickler v. Koota, 389 U.S. 241, 246-47 (1967) (quoting McNeese v. Bd. of Educ., 373 U.S. 668, 673 (1963)); see also Steffel v. Thompson, 415 U.S. 452, 464 (1974). 
to assertions of federal rights." 146 In sum, as Justice Frankfurter wrote, in enacting the Judiciary Act of 1875:

Congress gave the federal courts [a] vast range of power .... These courts ceased to be restricted tribunals of fair dealing between citizens of different states and became the primary and powerful reliances for vindicating every right given by the Constitution, the laws, and treaties of the United States. ${ }^{147}$

Additionally, as Justice Brennan recognized, Congress created federal question jurisdiction because of " the importance, and even necessity of uniformity of decisions throughout the whole United States" pertaining to federal issues. ${ }^{148}$ While there is no guarantee that all federal courts will provide the same interpretation of federal issues, their interpretations will surely be more uniform than those of courts from fifty different states. Moreover, federal courts - unlike state courts-have a unique expertise in resolving issues of federal law. They are "comparatively more skilled at interpreting and applying federal law and are much more likely correctly to divine Congress' intent in enacting legislation."149

Based on this historical context, a majordomo purposivist judge can reverse-engineer Congress's purpose in enacting the predecessor to $\S 1331$ : to enable litigants to benefit from the expertise, independence, and good faith of federal judges in adjudicating their federal rights and relevant issues of federal law. Majordomo purposivist judges must use their best judgment to arrive at an interpretation of $\S 1331$ that best effectuates this purpose. This Part will analyze and critique the Court's approach to interpreting the jurisdictional doctrines surrounding $§ 1331$ from the perspective of majordomo purposivism.

\section{The Scope of "Arising Under" Jurisdiction}

According to $\S 1331$, federal question jurisdiction exists so long as the cause of action "aris[es] under the Constitution, laws, or treaties of the United States." 150 There has been substantial confusion as to how to de-

146. Merrell Dow Pharms. Inc. v. Thompson, 478 U.S. 804, 827 n.6 (1986) (Brennan, J., dissenting). Justice Brennan also recognized that this belief still existed as of 1969, quoting an American Law Institute report indicating that federal courts apply federal law more understandingly than state courts. $I d$.

147. Felix Frankfurter \& James M. Landis, The Business of the Supreme Court: A Study in the Federal Judicial System 65 (1927); see also id. at 64 ("The Act of 1875 marks a revolution in [federal courts'] function. Sensitiveness to 'states' rights', fear of rivalry with state courts and respect for state sentiment, were swept aside by the great impulse of national feeling born of the Civil War.").

148. Merrell Dow, 478 U.S. at 826 (Brennan, J., dissenting) (quoting Martin v. Hunter's Lessee, 14 U.S. (1 Wheat.) 304, 347-48 (1816)).

149. Id. at 827 .

150. 28 U.S.C. $\S 1331$. Notably, this language mirrors that of Article III. U.S. ConsT. art. III, § 2 ("The judicial Power shall extend to all Cases . . . arising under this Constitution, the Laws of the United States, and Treaties made . ..."). While the Court has held that Article III "arising under" jurisdiction exists as long as a federal issue "forms an ingredient of the original cause," Osborn v. Bank of the U.S., 22 U.S. (9 Wheat.) 738, 823 (1824), the Court nevertheless has concluded that Congress provided a narrower jurisdictional grant in enacting $§ 1331$. See Merrell Dow, 478 U.S. at 807 ("[W]e have long con- 
termine whether a claim "arises under" federal law. Initially, the Court created a simple test. In American Well Works Co. v. Layne \& Bowler Co., Justice Holmes held that "[a] suit arises under the law that creates the cause of action." 151 Under Justice Holmes's test, federal question jurisdiction exists pursuant to $\S 1331$ only where the cause of action is created by federal law. In contrast, where the cause of action is created by state law, according to the American Well Works test, there is no federal question jurisdiction. This is true even if the adjudication of the state law claim will turn entirely on an issue of federal law.

A majordomo purposivist judge would reject this approach. Given the legal, political, and social context surrounding the enactment of the grant of general federal jurisdiction, it is implausible that Congress intended to draw the line for federal question jurisdiction merely based on whether a cause of action is created by federal or state law. ${ }^{152}$ Given the most plausible understanding of congressional goals, whether the cause of action giving rise to the federal law issue arises in the context of a state or federal claim is irrelevant. The purposes of the Act-including concern for state court bias against federal interests, federal court expertise, and the desire for uniform interpretation of federal law-apply regardless. Thus, a majordomo judge, whose goal is to best effectuate Congress's purposes in enacting the predecessor to $\S 1331$, would reject the notion that Congress intended such a federal versus state law distinction, and would reject Justice Holmes's approach.

The American Well Works approach still applies today, mostly for the sole purpose of inclusion. ${ }^{153}$ Under certain circumstances, federal jurisdiction can arise under federal law for purposes of $\S 1331$ where the cause of action is created by state law. ${ }^{154}$ In other words, "satisfying the American Well Works test [is] a sufficient but not a necessary means of meeting

strued the statutory grant of federal-question jurisdiction as conferring a more limited power."); Franchise Tax Bd. v. Constr. Laborers Vacation Tr., 463 U.S. 1, 8 n.8 (1983) ("Article III 'arising under' jurisdiction is broader than federal question jurisdiction under $\S 1331 . ”($ quoting Verlinden B.V. v. Cent. Bank of Nigeria, 461 U.S. 480, 495 (1983))). In so doing, the Court has adhered to a majordomo purposivist role. A majordomo purposivist judge would recognize that it is highly unlikely that Congress intended $\S 1331$ to have as broad of a reach as Article III because to do so would overwhelm federal courts with cases mostly unrelated to federal law. See William Cohen, The Broken Compass: The Requirement That a Case Arise "Directly" Under Federal Law, 115 U. PA. L. Rev. 890, 891 (1967); Paul J. Mishkin, The Federal "Question" in the District Courts, 53 Colum. L. Rev. 157, 162 (1953).

151. Am. Well Works Co. v. Layne \& Bowler Co., 241 U.S. 257, 260 (1916).

152. See Martin H. Redish, Federal Jurisdiction: Tensions in the Allocation of Judicial Power 97 (2d ed. 1990) (noting that Justices Holmes's approach "put[s] form over substance").

153. There are, however, rare exceptions to this rule, where even a claim arising out of federal law does not give rise to federal question jurisdiction because state law predominates. See, e.g., Shoshone Mining Co. v. Rutter, 177 U.S. 505, 509 (1900).

154. See Gunn v. Minton, 568 U.S. 251, 258 (2013) ("[W]here a claim finds its origins in state rather than federal law ... we have identified a 'special and small category' of cases in which arising under jurisdiction still lies." (quoting Empire HealthChoice Assurance, Inc. v. McVeigh, 547 U.S. 677, 699 (2006))). 
the statutory 'arising under' requirement." 155 The Court has struggled, however, in determining when a state-created cause of action does in fact give rise to federal question jurisdiction. For nearly fifty years, the Court used the test announced in Smith v. Kansas City Title \& Trust Co.: "[W]here it appears from the bill ... of the plaintiff that the right to relief depends upon the construction or application of the Constitution or laws of the United States ... [a] District Court has jurisdiction under [§ 1331]." 156 In so holding, the Court rejected the artificially narrow approach of American Well Works. Such an approach is consistent with the majordomo purposivist model of statutory interpretation because it recognizes the fundamental congressional goal of allowing litigants to obtain federal adjudication when federal rights and interests are at stake.

While Smith controlled for many years, more recently the Court has significantly limited federal question jurisdiction over state-created causes of action. In 1986 the Court, despite purporting not to overrule Smith, significantly narrowed arising under jurisdiction. In Merrell Dow, the plaintiffs brought state negligence claims against a pharmaceutical company in state court, and the plaintiffs argued that a violation of the federal Food, Drug, and Cosmetic Act (FDCA) gave rise to a rebuttable presumption of negligence. ${ }^{157}$ The defendants sought to remove to federal court, arguing that under Smith, federal question jurisdiction was appropriate. ${ }^{158}$ The Court rejected this argument, denying federal question jurisdiction. ${ }^{159}$ The Court reasoned that because Congress did not intend to include a private federal remedy for violations of misbranding laws in the FDCA, Congress must have determined that misbranding claims did not warrant federal question jurisdiction. ${ }^{160}$ The Court purported to distinguish Smith by finding that the federal statute at issue in the case at hand was less "important" than the constitutional issue in Smith. ${ }^{161}$ Justice Brennan dissented, arguing that the Court's approach was contrary to congressional purpose and advocating for adherence to the standard enunciated in Smith. ${ }^{162}$ Justice Brennan properly recognized the importance of "examin[ing] the reasons for Congress' decisions to grant or withhold . . . federal jurisdiction," a task the majority failed to undertake. ${ }^{163}$

The majority did look to congressional purpose, but for the wrong statute; it examined the FDCA rather than $\S 1331$. The Court reasoned "that

155. Linda Mullenix, Martin Redish \& Georgene Vairo, Understanding FedERAL COURTS AND JuRISDiction 215 (2d ed. 2015).

156. Smith v. Kan. City Title \& Tr. Co., 255 U.S. 180, 199 (1921).

157. Merrell Dow Pharms. Inc. v. Thompson, 478 U.S. 804, 806 (1986).

158. Id.

159. Id. at 817 .

160. Id. at 814 ("[A] congressional determination that there should be no federal remedy for the violation of [the FDCA] is tantamount to a congressional conclusion that the presence of a claimed violation of the statute as an element of a state cause of action is insufficiently 'substantial' to confer federal-question jurisdiction.").

161. Id. at 814 n.12.

162. Id. at 824-28 (Brennan, J., dissenting).

163. Id. at 826 . 
the congressional determination that there should be no federal remedy for the violation of [the FDCA] is tantamount to a congressional conclusion that the presence of a claimed violation of the statute as an element of a state cause of action is insufficiently 'substantial' to confer federalquestion jurisdiction." 164 This conclusion is logically indefensible. The Court "confused the substantive issue of the [FDCA's] reach with the jurisdictional question of whether a state cause of action incorporating federal law gives rise to federal question jurisdiction." 165 Indeed, "a congressional decision not to provide a federal remedy does not necessarily imply congressional disapproval of the provision of a federal forum for adjudication of a state cause of action turning on the interpretation of that federal statute." 166 If the Court was concerned with Congress's intent in enacting the FDCA, it needed to engage in a substantive preemption analysis; it is possible that Congress intended to preempt a state cause of action incorporating a private remedy by declining to include a private remedy in the FDCA. ${ }^{167}$ But in determining whether federal jurisdiction is appropriate, a majordomo judge must instead focus on the meaning and purposes of $\S 1331$.

Majordomo purposivist judges must use their common sense and best judgment in interpreting $\S 1331$ because the text of the federal question jurisdiction statute is not entirely clear on its face. Under the majordomo purposivist approach, the judges' goal must be to employ their implementational discretion to achieve Congress's purposes in enacting the statute as much as possible. To glean congressional purpose, a majordomo judge examines, among other things, the historical context of the statute. The historical context surrounding the 1875 jurisdictional grant suggests that Congress desired that litigants would have the ability to adjudicate issues of federal law in federal court. ${ }^{168}$

By contrast, there is no evidence that Congress preferred for federal courts to consider the "importance" of the federal issue, as the Court suggested in Merrell Dow. There is no principled reason for federal courts to distinguish federal issues based on whether the court believes the issue is sufficiently "important." Indeed, "Congress presumably thinks all of its laws are important, even if it does not provide a [specific] cause of action."169 Therefore, the Court in Merrell Dow was wrong to hold that federal question jurisdiction was improper merely because the FDCA did not include a private damage remedy. A majordomo purposivist judge would instead recognize that the adjudication of the FDCA is the very type of issue where federal courts' expertise, uniformity, and sensitivity to federal issues is desired, and thus that Congress likely envisioned federal

164. Id. at 814 (majority opinion).

165. REDISH, supra note 152 , at 100.

166. Id.

167. Id.

168. See supra notes $139-49$ and accompanying text.

169. Hessick, supra note 25, at 921; see also Merrell Dow, 478 U.S. at 828 (Brennan, J., dissenting). 
jurisdiction in such a situation. To best effectuate those wishes, a court adhering to majordomo purposivism would exercise federal jurisdiction.

Professor Friedman pointed to Merrell Dow as an illustration of the dialogic approach. ${ }^{170} \mathrm{He}$ correctly recognized that "Congress's intent has had little or nothing to do with the Court's decisions concerning what constitutes a federal question" 171 and, more specifically, that the Court in Merrell Dow was concerned more with "judicial administration than with any congressional command concerning when to exercise federal question jurisdiction." ${ }^{172} \mathrm{He}$ apparently has no problem with the Court's failure to consider congressional purpose because it is appropriately participating in a dialogue in shaping federal question jurisdiction.

First, he suggests that because "the federal question jurisdictional grant has remained generally the same for over one hundred years," Congress has participated in a dialogue through silence, suggesting its approval of the Court's outcome. ${ }^{173}$ But as already noted, congressional failure to act is not equivalent to the act of lawmaking and in no way implies that Congress endorses the jurisdictional policy advocated for by the Court. ${ }^{174}$ Second, Professor Friedman suggests that the Court in Merrell Dow "made it easy for Congress to change [the] result, albeit on a case-by-case basis," by "creat[ing] [a] cause of action." 175 Professor Friedman, like the majority in Merrell Dow, fails to focus on $\S 1331$ as a controlling statute. In contrast, majordomo purposivist judges would analyze $\S 1331$ itself and use their best judgment to recognize that, based on historical context, Congress likely enacted $\S 1331$ to provide federal court jurisdiction over actually raised federal law issues regardless of whether Congress created a specific cause of action.

Twenty years after Merrell Dow, in Grable \& Sons Metal Products v. Darue Engineering \& Manufacturing, the Court articulated a new fourprong test to implement the Merrell Dow approach: federal question jurisdiction is proper over a state-created cause of action where the statelaw claim (1) "necessarily raise[s] a stated federal issue"; (2) the federal issue is "actually disputed"; (3) the federal issue is "substantial"; and (4) where a "federal forum may entertain [the federal issue] without disturbing any congressionally approved balance of federal and state judicial responsibilities." 176 Unlike the Smith test, Grable allows federal courts to reject federal question jurisdiction for a claim that necessarily raises an actually disputed federal issue simply because the cause of action is technically a state-law claim. ${ }^{177}$ Under Grable, a federal court can reject federal question jurisdiction if, in the Court's mind, the federal issue in a

170. Friedman, supra note 5, at 22-23.

171. Id. at 24 .

172. Id. at 23 .

173. Id. at 24.

174. See supra Section III.C.2.

175. Friedman, supra note 5, at 24.

176. Grable \& Sons Metal Prods., Inc. v. Darue Eng'g, 545 U.S. 308, 314 (2005).

177. Compare id., with Smith v. Kan. City Title \& Tr. Co., 255 U.S. 180, 199 (1921). 
state-law claim is not important, or if providing federal jurisdiction would disturb the "balance of federal and state judicial responsibilities"-in other words, if exercising federal jurisdiction would overburden the federal docket with cases that would otherwise be in state court. ${ }^{178}$

A majordomo purposivist would also reject this approach. First, the Court in Grable, as in Merrell Dow, continued to focus on whether the federal issue was substantial. ${ }^{179}$ Under the majordomo purposivist approach, the so-called importance of the federal issue is immaterial. Additionally, the Court's focus on the balance of federal and state judicial responsibilities is an unprincipled expansion of judicial power. When Congress passed the Judiciary Act of 1875 and created a general grant of federal question jurisdiction, it of course knew that it would increase federal courts' caseload. As one scholar recognized, in passing the federal question jurisdiction statute "Congress [was] convinced that the necessity of evading local prejudice was greater than the necessity of relieving the federal courts of their heavy burden[s]."180

By contrast, there is nothing in $\S 1331$ or its surrounding historical context that gives even the slightest indication that Congress adopted the statute with the goal that federal jurisdiction turn on the impact on the federal docket. To deny federal jurisdiction because the impact on the federal docket is great, as Grable suggests, is diametrically opposed to Congress's purpose in creating federal question jurisdiction. In fact, the federal issues that are most appropriate to be adjudicated in a federal forum are those that are recurring. The more common the federal issue, the more likely cases will arise, and the more necessary it is for federal courts to exercise jurisdiction to ensure uniform interpretation of the particular federal issue.

The Court's failure to examine congressional purpose is evident from its attempt to distinguish Grable from Merrell Dow. In both cases, federal jurisdiction was sought over a state-created claim that incorporated an issue of federal law. ${ }^{181}$ According to the Grable Court, federal jurisdiction was inappropriate in Merrell Dow because "[a] general rule of exercising federal jurisdiction over state claims resting on federal mislabeling and other statutory violations would ... have heralded a potentially enormous shift of traditionally state cases into federal courts." 182 The Court distinguished Grable from Merrell Dow by noting that "it is the rare state quiet title action that involves contested issues of federal law. Consequently, jurisdiction ... would not materially affect, or threaten to affect, the normal currents of litigation." 183 The Court found jurisdiction permis-

178. See Grable, 545 U.S. at 314; Andrew D. Bradt, Grable on the Ground: Mitigating Unchecked Jurisdictional Discretion, 44 U.C. DAvis L. REv. 1153, 1183 (2011); Hessick, supra note 25, at 922.

179. See Grable, 545 U.S. at 312.

180. Bergman, supra note 144 , at 28.

181. See id.; Merrell Dow Pharms. Inc. v. Thompson, 478 U.S. 804, 805 (1986).

182. Grable, 545 U.S. at 319.

183. Id. (citation omitted). 
sible in Grable because the impact on federal courts' dockets would be minor, ${ }^{184}$ whereas in Merrell Dow the impact would potentially be significant. ${ }^{185}$ However, a majordomo purposivist judge would recognize that federal jurisdiction is particularly necessary in a case like Merrell Dow for the very reason that the federal issue is likely to arise more often.

The Court further narrowed federal question jurisdiction in Gunn v. Minton. ${ }^{186}$ While reaffirming the general framework of Grable's fourprong test, the Court significantly modified the third prong. The Court stated that "it is not enough that the federal issue be significant to the particular parties in the immediate suit .... The substantiality inquiry under Grable looks instead to the importance of the issue to the federal system as a whole." 187 Gunn involved a "legal malpractice claim ... based on an alleged error in a patent case." 188 The issue was whether there was federal jurisdiction under 28 U.S.C. $§ 1338{ }^{189}$ because the state legal malpractice claim was related to federal patent law. ${ }^{190}$ The Court held that it did not have jurisdiction under $\S 1338$ because the federal issue, while important to the individual litigant, was not significant to the federal system as a whole. ${ }^{191}$ The Court stressed the fact that based on the nature of the malpractice claim, "[n]o matter how the state courts resolve[d] [the] hypothetical 'case within a case,' it [would] not change the real-world result of the prior federal patent litigation"192 and the "patent [would] remain invalid." 193 The Court emphasized that the Federal Circuit was "not bound by state court case-within-a-case patent rulings" when determining "nonhypothetical patent questions" and was unsure that those rulings could have collateral estoppel effect. ${ }^{194}$

Focusing on the extent to which the federal issue is systemically important effectively transforms federal question jurisdiction in the district court into something approaching a certiorari standard for Supreme Court review. ${ }^{195}$ In emphasizing the federal issue's systemic impact, the Court completely ignores the impact of this standard on the rights of individual litigants. The very fact that Congress chose not to grant federal jurisdiction under $\S 1331$ makes clear that litigant choice was of central

\footnotetext{
184. Id.

185. Merrell Dow, 478 U.S. at 811-12.

186. See 568 U.S. 251 (2013).

187. Id. at 260 (emphasis added).

188. Id. at 255 .

189. "The district courts shall have original jurisdiction of any civil action arising under any Act of Congress relating to patents .... . No State court shall have jurisdiction over any claim for relief arising under any Act of Congress relating to patents . . . ." 28 U.S.C $\S 1338(\mathrm{a})$. The Court interprets arising under jurisdiction under $\S 1331$ and $\S 1338$ (a) identically, and therefore, "appl[ies] [its] $\$ 1331$ and $\S 1338$ (a) precedents interchangeably." Gunn, 568 U.S. at 257.

190. Gunn, 568 U.S. at 255.

191. Id. at 264.

192. Id. at 261 .

193. Id.

194. Id. at 262 .

195. See Sup. Cт. R. 10 ("A petition for a writ of certiorari will be granted only for compelling reasons.").
} 
importance. While, of course, this is not true of the patent jurisdiction involved in Gunn, where federal jurisdiction is exclusive, the Gunn Court's holding was clearly intended to be applicable to general federal question jurisdiction as well. ${ }^{196}$ Thus, by ignoring the individual litigant's interest in having the benefit of federal judicial expertise, the Court failed to adhere to the obvious purposes served by general federal question jurisdiction.

More importantly, whether the Court was right or wrong in its conclusion, its failure even to explore the purposes served by the underlying jurisdictional statute underscores its failure to recognize its institutional obligation within our constitutional democratic system. The Court approached the issue as if it were purely a matter of federal common law, without the slightest inquiry into legislative purpose. In this sense, the Court's effort failed to adhere to the majordomo purposivist standard, dictated by institutionalist considerations of our governmental system. 197

In sum, a majordomo purposivist would reject the current test used to determine federal question jurisdiction. In Merrell Dow, Grable, and Gunn, the Court improperly abandoned its limited role of statutory interpretation. Majordomo judges would instead use their best judgment to find, based on examination of historical context, that Congress enacted general federal question jurisdiction in order to ensure that individuals have the option to benefit from the unique advantages provided by federal judges and procedures.

\section{The "Well-Pleaded Complaint" Rule}

The so-called well-pleaded complaint rule states that "a suit arises under the Constitution and laws of the United States only when the plaintiff's statement of his own cause of action shows that it is based upon those laws or that Constitution." 198 Moreover, arising under jurisdiction cannot be found-even when an extremely important federal issue is involved-if the plaintiff raises that issue in the form of an "anticipated defense to his cause of action and asserts that the defense is invalidated by some provision of the Constitution of the United States," no matter how likely it is that the federal issue will arise, and even if it will determine the outcome of the case. ${ }^{199}$ By applying the majordomo purposivist

196. See generally Gunn, 568 U.S. at 253-65.

197. If the Court had confined its holding to cases arising under statutes providing for exclusive federal jurisdiction, its approach would have been more plausible. It did not do so, however, and jurisdiction under $\S \S 1331$ and 1338 has always been deemed fungible. See id. at 257.

198. Louisville \& Nashville R.R. v. Mottley, 211 U.S. 149, 152 (1908).

199. Id. Though Mottley is the well-pleaded complaint rule case most commonly cited by scholars, the Court recognized the rule well before that decision. See Metcalf v. Watertown, 128 U.S. 586, 589 (1888) ("Where . . the original jurisdiction of a [federal court] is invoked upon the sole ground that the determination of the suit depends upon some question of a Federal nature, it must appear, at the outset, from the declaration or the bill of the party suing, that the suit is of that character.”); Tennessee v. Union \& Planters' Bank, 152 U.S. 454, 464 (1894) ("[A] suggestion of one party, that the other will or may set up a claim 
approach, which itself is an outgrowth of the foundational institutionalist model of federal jurisdiction, we provide an entirely new perspective on the rule.

A majordomo purposivist would seek to determine whether the wellpleaded complaint rule is consistent with the purposes that motivated the enactment of the general grant of federal question jurisdiction. Initially, one should note that the statute's text makes no reference to the rule. Section 1331 simply declares that federal courts "have original jurisdiction of all civil actions arising under" federal law. ${ }^{200}$ In evaluating the validity of the well-pleaded complaint rule, a majordomo purposivist judge first asks whether the text-in particular, the words "arising under"-requires the rule. The text alone fails to answer the question. While the words "arising under" are not inconsistent with a requirement that the cause of action must appear on the face of the plaintiff's complaint, neither do they expressly dictate it.

Because the text is ambiguous on the matter, a majordomo purposivist judge must reverse-engineer congressional purpose. The judge would initially focus on the broad interest Congress sought to protect in creating a general grant of federal question jurisdiction. As previously noted, Congress recognized the systemic and structural advantages of the adjudication of issues of federal law in federal court: federal court offers the advantage of federal judicial expertise, experience with issues of federal law, and uniformity that flows from this adjudication. ${ }^{201}$ Recognizing this broad congressional intent, the majordomo purposivist judge would use implementational discretion to determine whether the well-pleaded complaint rule best effectuates Congress's goals. In other words, the majordomo purposivist judge would ask whether Congress intended to draw this distinction. At first glance, the answer appears to be no. Significant federal issues could arise on which the outcome of the case would turn, even if they do not appear on the face of the plaintiff's complaint. Indeed, a federal issue first raised in a defendant's answer could be dispositive; the entire cause of action could turn on a court's interpretation of that federal issue.

Louisville \& Nashville Railroad Co. v. Mottley illustrates this point. There, plaintiffs alleged that the defendants breached an agreement that the defendants would provide the plaintiffs with free rail passes for life. ${ }^{202}$ Plaintiffs anticipated that the defendants would argue that federal law "for[bade] the giving of free passes or free transportation" and argued that the federal law did not apply, or alternatively, that the law violated the Fifth Amendment. ${ }^{203}$ Though the plaintiffs' claim was grounded in

under the Constitution or laws of the United States, does not make the suit one arising under that Constitution or those laws.").

200. 28 U.S.C. $\S 1331$.

201. See Merrell Dow Pharms. Inc. v. Thompson, 478 U.S. 804, 826-27 (1986) (Brennan, J., dissenting).

202. Mottley, 211 U.S. at 150.

203. Id. 
state law, the Court acknowledged that it was "very likely" the federal issue would arise in the course of the litigation. ${ }^{204}$ Indeed, it was probable that the outcome of the case would turn on that issue of federal law. Nevertheless, the Court refused to find arising under jurisdiction. ${ }^{205}$ From a majordomo purposivist perspective, this conclusion is surely incorrect. If an issue of federal law is "very likely" to arise and to be dispositive, the interests Congress sought to protect are triggered, whether or not the issue appears in the plaintiff's complaint. Use of the well-pleaded complaint rule, then, can directly undermine the fundamental goals sought to be attained by the legislative adoption of federal question jurisdiction in the first place. Recognizing that it was unlikely that Congress intended to draw this counterproductive distinction, a majordomo purposivist would deem the rule nothing more than a judge-made dictate designed to artificially restrict federal question jurisdiction.

The response could be made that the legislative judgment was grounded in a number of often-competing considerations and that those considerations may justify a limitation on federal question jurisdiction. However, in order to reach such a conclusion, the competing practicalities must be especially convincing. In other words, the inefficiencies that would result from allowing arising under jurisdiction, where the federal issue is raised for the first time in the defendant's answer, must be so compelling that they overcome the strong presumption against the wellpleaded complaint rule.

One rationale for the well-pleaded complaint rule is that to allow arising under jurisdiction where the federal issue appears on the face of the complaint solely as a response to an anticipated defense would be unduly burdensome and would undermine federal court efficiency. In such situations, there can be no certainty that the defendant will actually raise the federal defense, giving rise to an inefficient waste of federal judicial resources. ${ }^{206}$ In addition, Judge Posner has argued that "[i]n many [such cases] the [anticipated] federal defense would have little merit-would, indeed, have been concocted purely to confer federal jurisdiction-yet this fact might be impossible to determine, with any confidence, without having a trial before the trial." 207 But these concerns are either overstated or illogical.

More likely than not, if a plaintiff anticipates that the defendant will raise an issue of federal law in defense, the defendant will in fact raise that issue. In the relatively few cases in which the defendant does not actually raise the federal defense, a federal court-either sua sponte or by defendant's motion - can dismiss the case at any time for lack of subject

204. Id. at 152

205. Id.

206. Martin H. Redish, Reassessing the Allocation of Judicial Business Between State and Federal Courts: Federal Jurisdiction and "The Martian Chronicles," 78 VA. L. Rev. 1769, 1796 (1992).

207. Id. (first and second alterations in original) (quoting PosNer, CRISIS AND ReFORM, supra note 130, at 190). 
matter jurisdiction. ${ }^{208}$ Moreover, courts can simply enforce Rule 11 of the Federal Rules of Civil Procedure to deter frivolous lawsuits. ${ }^{209}$ And motions to dismiss, ${ }^{210}$ motions for summary judgment, ${ }^{211}$ and motions for judgments on the pleadings ${ }^{212}$ can be used to avoid the "trial before the trial" concern. In any event, Judge Posner's concern about lack of substantive merit applies to well-pleaded issues of federal law as much as it does to anticipated federal defenses. Thus, it proves far too much.

More importantly, even if such concerns are assumed to be legitimate, it does not resolve the question of whether these concerns overcome the compelling competing interest, clearly manifested in the legislation, in having federal issues resolved by federal courts. Consider the facts of Mottley. The entire case would almost certainly turn on the constitutionality of a federal statute. Yet because of the well-pleaded complaint rule, that federal issue would have to be determined by state courts, with only the uncertain possibility of Supreme Court review. However, in creating the well-pleaded complaint rule, the Court did not even consider this competing interest in having federal issues resolved by federal courts, despite its clear grounding in legislative purpose.

In Skelly Oil Co. v. Phillips Petroleum Co., the Court announced two additional rationales for the well-pleaded complaint rule. ${ }^{213}$ From a majordomo purposivist perspective, neither is persuasive. First, the Court articulated a concern for docket control and claimed that without the well-pleaded complaint rule, there would be a vast increase in litigation in federal court. ${ }^{214}$ While it is not unreasonable to believe that avoiding overburdening the courts was an implicit assumption of the Congress that enacted general federal question jurisdiction, there is no logical basis for concluding that the well-pleaded complaint rule would be the method contemplated by Congress. Federal issues can be just as important to the outcome of the case whether they arise in the complaint or in the answer. Excluding federal issues raised in the answer would make no more sense as a means of reducing dockets than excluding federal issues raised in the complaint.

The Skelly Oil Court also reasoned that to disregard the well-pleaded complaint rule would "embarrass [federal courts] - and [the Supreme] Court on potential review-in that matters of local law may often be involved." 215 But federal courts often decide issues of state law when exercising diversity jurisdiction, supplemental jurisdiction, and even federal question jurisdiction. The risk of embarrassment is no greater when the

208. Fed. R. Civ. P. 12(h)(3).

209. See FeD. R. Civ. P. 11(c) (providing the court the power to impose sanctions on attorneys who advance frivolous claims).

210. Fed. R. Civ. P. 12(b).

211. FED. R. Civ. P. 56(a)

212. FED. R. CIV. P. 12(c).

213. Skelly Oil Co. v. Phillips Petroleum Co., 339 U.S. 667, 673 (1950).

214. Id.

215. Id. 
federal issue is raised in the answer than when it is raised in the complaint. In any event, the existence of diversity jurisdiction demonstrates congressional acceptance of federal adjudication of state law issues.

Professor Friedman, in developing his dialogic approach, recognized that the well-pleaded complaint rule has no basis in Congress's wishes. ${ }^{216}$ Presumably, Professor Friedman does not have a problem with this fact because, if Congress so chooses, it could "tell" the Court it is wrong as part of the dialogic process. But from a majordomo purposivist perspective, this rationale is troubling. It is the role of the federal courts to be subservient to Congress's decisions and to use implementational discretion to effectuate Congress's goals. The judiciary cannot be allowed to supersede Congress's jurisdictional policy choices with its own normative preferences on the grounds that Congress has the power to override the judicial usurpation of its authority.

The only feasible way to maintain the well-pleaded complaint rule while still effectuating Congress's legislative purposes would be to allow either party to remove a case from state court to federal court if and when the defendant raises the federal issue. Unfortunately, Congress has explicitly precluded such an option. The removal statute, unlike $\S 1331$, is unambiguous. ${ }^{217}$ Congress has expressly and unambiguously determined that only a defendant may remove a case to federal court, and the defendant may only do so when the district court has original jurisdiction. ${ }^{218}$ The removal statute's clear directives leave no other option; in order to effectuate Congress's purpose in creating arising under jurisdiction, and to enable issues of federal law to be adjudicated by federal courts even where the federal issue first appears as a defense to state-law claims, a majordomo purposivist must reject the well-pleaded complaint rule.

Whatever one thinks of the arguments relied upon to justify the wellpleaded complaint rule, they largely disappear when the federal defense is raised not by a defendant in their answer, but by the plaintiff in a complaint under the Declaratory Judgment Act. ${ }^{219}$ In classic declaratory judgment actions, prospective defendants are permitted to file suit in order to legally determine their rights. ${ }^{220}$ In such a situation, the defendant-who is also the prospective plaintiff-has no alternative but to litigate the federal issue. There is no uncertainty as to whether the federal issue will actually be raised. Thus, there is no risk of wasted effort on the part of the federal court because the defendant failed to raise their anticipated federal defense. Nevertheless, the Court has not hesitated in applying the

216. Friedman, supra note 5, at 22 ("Judicial decisions developing and relying on the well-pleaded complaint rule ... generally neglect even to mention that a statute is being construed, let alone attempt to discern congressional intent.").

217. See 28 U.S.C. $\$ 1441$.

218. Id. § 1441(a).

219. Id. $§ 2201$ ("In a case of actual controversy within its jurisdiction . . . any court of the United States, upon the filing of an appropriate pleading, may declare the rights and other legal relations of any interested party seeking such declaration, whether or not further relief is or could be sought.").

220. See id. §2201(a). 
well-pleaded complaint rule in this context. ${ }^{221}$ Ironically, in so doing, the Court is, as a refreshing change, actually focused on the purpose of the relevant legislation. But the legislation on which it focuses is not the general federal question statute but rather the Declaratory Judgement Act. The Court continues to ignore the legislative goals underlying the grant of general federal question jurisdiction. Had it not ignored these goals, it would have recognized that it is not difficult to harmonize the goals of the two statutes.

The Court first applied the well-pleaded complaint rule to declaratory judgment actions in Skelly Oil. ${ }^{222}$ There, purchasers contracted to buy oil from Skelly for ultimate resale, and Skelly was permitted to terminate the contract if the ultimate buyer did not obtain a certificate of public convenience and necessity from the Federal Power Commission. ${ }^{223}$ Subsequently, a purchaser sought a declaratory judgment that the contract was still valid because the ultimate buyer did obtain a proper certificate under federal law. ${ }^{224}$ The Court refused to find federal question jurisdiction and instead created a new analytical model to examine the question of federal question jurisdiction for declaratory judgment claims: courts must look to a hypothetical coercive complaint and determine whether a federal issue would appear on that hypothetical well-pleaded complaint. ${ }^{225}$ Using this new framework, the Court held that because absent a declaratory judgment device the plaintiff would sue for breach of contract, and since the federal issue of the validity of the certificate of public convenience would only have appeared in Skelly's defense, the cause of action did not arise under federal law. ${ }^{226}$

Taking the well-pleaded complaint rule as a given, under a majordomo purposivist approach, a court would look to Congress's purposes in enacting the Declaratory Judgment Act. A majordomo judge must determine whether Congress intended to preclude federal question jurisdiction where a federal issue would not appear on the hypothetical complaint in the coercive action absent the declaratory judgment action.

The Court in Skelly Oil, relying on its assessment of Congress's purpose in passing the Declaratory Judgment Act, reasoned that Congress had not intended to expand the scope of arising under jurisdiction. It held that " $[t]$ he operation of the Declaratory Judgment Act is procedural only" 227 and that while "Congress enlarged the range of remedies available in the federal courts[,] [it] did not extend their jurisdiction."228 Some scholars have suggested, based on an examination of legislative history,

\footnotetext{
221. See, e.g., Skelly Oil Co. v. Phillips Petroleum Co., 339 U.S. 667 (1950).

222. Id. at 673-74.

223. Id. at 669 .

224. Id. at $670-71$.

225. See id. at 673-74; Donald L. Doernberg \& Michael B. Mushlin, The Trojan Horse: How the Declaratory Judgment Act Created a Cause of Action and Expanded Federal Jurisdiction While the Supreme Court Wasn't Looking, 36 UCLA L. REv. 529, 544 (1989).

226. Skelly Oil, 339 U.S. at 672-74.

227. Id. at 671 (quoting Aetna Life Ins. Co. v. Haworth, 300 U.S. 227, 240 (1937)).

228. Id.
} 
that the Court was incorrect because Congress did in fact intend to enlarge the scope of federal courts' jurisdiction by adopting the Declaratory Judgment Act. ${ }^{229}$ If those scholars are correct, then the Court's opinion relied on a flawed understanding of congressional purpose and would thus be rejected by a majordomo purposivist.

But even if the Court were correct, it still failed to act as Congress's majordomo because it failed to harmonize the goals of the two statutes. The legislative goal underlying general federal question jurisdiction, as described earlier, is to provide litigants the opportunity to benefit from the unique advantages provided by the federal judiciary in interpreting and enforcing federal law, while not unduly burdening the federal courts with potentially wasteful litigation that will ultimately prove to present no federal issues. ${ }^{230}$ On the other hand, the relevant legislative goal underlying the Declaratory Judgment Act, we assume for purposes of argument, was to be neutral towards the existing scope of federal jurisdiction. The harmonization of these two seemingly competing goals would have been obvious to the Court had it bothered to engage in a majordomo purposivist analysis of both statutes. The goal of the Declaratory Judgment Act was not to expand federal jurisdiction, and the federal question statute provides that cases that may turn on the resolution of a question of federal law fall within federal court jurisdiction. To ignore the wellpleaded complaint rule in the context of a classic declaratory judgment action (i.e., one brought by a prospective defendant), then, does not "expand" federal jurisdiction because the legal standards of federal jurisdiction remain the same: cases in which a potentially dispositive issue of federal law actually "arise under" federal law. The only difference is that, because of the collateral impact of the Declaratory Judgment Act, more cases now clearly satisfy that standard. But because the Court in Skelly Oil, much like the Court in Mottley, never tested the well-pleaded complaint rule by the legislative goals sought to be attained by the general federal question statute, no purposivist harmonization process took place.

The Court compounded its interpretive failure in its subsequent decision in Franchise Tax Board v. Construction Laborers Vacation Trust. There, the Court, while admitting that "Skelly Oil does not apply of its own force to state declaratory judgment statutes," held that "fidelity to its spirit leads us to extend it to state declaratory judgment actions as well." 231 This was so even though the very foundation of the Court's decision in Skelly Oil-the desire not to expand federal jurisdiction-had no applicability whatsoever in the state declaratory judgment context. More-

229. See Doernberg \& Mushlin, supra note 225, at 549 ("Congress approved the declaratory judgment device precisely because it expanded the scope of federal court power and the timing of its exercise."). After examining legislative history, they concluded that "Congress knew that the Act would permit parties otherwise unable to sue in federal court to use that forum." Id. at 562 .

230. Supra Section V.A.

231. Franchise Tax Bd. v. Constr. Laborers Vacation Tr., 463 U.S. 1, 17-18 (1983) (emphasis omitted). 
over, the substantive issue presented in Franchise Tax Board-whether the Employee Retirement Income Security Act (ERISA) preempted state law-concerned important issues of federal law and congressional policy. 232

\section{B. Diversity Jurisdiction}

The diversity jurisdiction statute, 28 U.S.C. $§ 1332$, provides that federal courts "shall have ... jurisdiction of all civil actions where the matter in controversy exceeds the sum or value of $\$ 75,000$, exclusive of interest and costs, and is between citizens of different States." ${ }^{233}$ Like $\S 1331$, $\S 1332$ is not clear on its face on several important questions. Because the statute is ambiguous on these issues, a majordomo purposivist judge must discern congressional purpose in order to resolve them in a manner that best effectuates the statute's purpose. This Section will apply the majordomo purposivist approach to critique a number of the Court's current diversity doctrines.

Diversity jurisdiction has never lacked critics, including both members of the federal judiciary and legal scholars. Controversy surrounded the initial creation of a grant of original jurisdiction based on diversity at the Constitutional Convention, at the First Congress, and in state legislatures. ${ }^{234}$ Indeed, some commentators suggest that no area of federal jurisdiction was more controversial than diversity jurisdiction. 235 Over time, the controversy has not diminished. ${ }^{236}$ In 1976, Professor David Shapiro conducted a survey of the federal judiciary's views on diversity jurisdiction. ${ }^{237}$ A total of 310 federal circuit and district court judges (65 circuit judges and 245 district judges) responded to the survey. ${ }^{238}$ Of those judges, $176-56.8 \%$ - supported the elimination of diversity jurisdiction. ${ }^{239}$ Of the 111 who supported retaining diversity jurisdiction in some

232. See id. at 6 .

233. 28 U.S.C. $\S 1332(a)(1)$.

234. Hessel E. Yntema \& George H. Jaffin, Preliminary Analysis of Concurrent Jurisdiction, 79 U. PA. L. Rev. 869, 871-72 (1931).

235. See 13E Charles Alan Wright, Arthur R. Miller \& Edward H. Cooper, Federal Practice and Procedure § 3601, at 2-5, 20-22 (3d ed. 2009); see also, e.g., Henry J. Friendly, The Historic Basis of Diversity Jurisdiction, 41 HARv. L. REv. 483, 487 (1928); Charles Warren, New Light on the History of the Federal Judiciary Act of 1789, 37 HARv. L. Rev. 49, 81 (1923).

236. See Larry Kramer, Diversity Jurisdiction, 1990 BYU L. Rev. 97, 98 ("Few issues of judicial administration have evoked the same degree of concern and attention.").

237. See David L. Shapiro, Federal Diversity Jurisdiction: A Survey and a Proposal, 91 Harv. L. Rev. 317, 332-39 (1977). Professor Shapiro, based on the survey, determined that evidence "support[ed] the view that diversity jurisdiction may be more warranted, and more useful, in some districts than in others." Id. at 339. Thus, he concluded that a "uniform national solution seems less desirable," and that "the best plan . . . may be to give each district a choice, to be exercised by a majority of that district's judges on regular active status" as to whether to keep, restrain, or eliminate diversity jurisdiction. Id. at 340 .

238. Id. at 333-34.

239. Id. A total of 40 of the 65 circuit judges $(61.5 \%)$ and 136 of the 245 district judges (55.5\%) supported elimination. Id. 
form, just $38-12.3 \%$ - preferred to leave diversity jurisdiction as is. ${ }^{240}$ The others supported retaining diversity jurisdiction in some limited form, such as restricting the categories of cases where diversity jurisdiction is permissible or increasing the jurisdictional minimum amount in controversy. ${ }^{241}$

Moreover, numerous federal judges-including Supreme Court Justices-have openly criticized diversity jurisdiction. Justice Brandeis was an early critic. He both lobbied Congress to restrict diversity jurisdiction $^{242}$ and encouraged then-Professor Frankfurter to criticize it. ${ }^{243}$ Justice Frankfurter later expressed concern about diversity jurisdiction from the bench, noting "the mounting mischief inflicted on the federal judicial system" it caused. ${ }^{244}$ Justice Jackson likewise criticized diversity jurisdiction, writing that "the greatest contribution that Congress could make to the orderly administration of justice in the United States would be to abolish [diversity jurisdiction]." 245 More recently, Chief Justice Burger wrote that "diversity cases have no more place in the federal courts," 246 and Chief Justice Rehnquist suggested that "elimination of diversity jurisdiction is an idea that merits serious consideration." 247 Many lower federal court judges have also written critically about diversity jurisdiction. ${ }^{248}$

240. Id. A total of 8 of the 65 circuit judges (12.3\%) and 30 of the 245 district judges $(12.2 \%)$ preferred to leave diversity jurisdiction as is. $I d$.

241. Id.

242. Edward A. Purcell, Jr., Brandeis and the Progressive Constitution: Erie, the Judicial Power, and the Politics of the Federal Courts in TwentiethCentury America 144 (2000) ("At every opportunity Brandeis urged congressmen to limit diversity.").

243. Id. ("Brandeis exerted a public influence through Frankfurter. His letters to Frankfurter ... often read like directives from a commanding general. He repeatedly urged Frankfurter to have his students publish work on controversial jurisdictional topics, and he encouraged and guided Frankfurter in producing his own immediately useful scholarship." (footnote omitted)). Justice Brandeis was successful. See, e.g., Felix Frankfurter, A Note on Diversity Jurisdiction -In Reply to Professor Yntema, 79 U. PA. L. Rev. 1097 (1931) [hereinafter Frankfurter, A Note on Diversity]; Felix Frankfurter, Distribution of Judicial Power Between United States and State Courts, 13 CoRnell L.Q. 499 (1928).

244. Lumbermen's Mut. Cas. Co. v. Elbert, 348 U.S. 48, 54 (1954) (Frankfurter, J., concurring); see also Nat'l Mut. Ins. Co. v. Tidewater Transfer Co., 337 U.S. 582, 651 (1949) (Frankfurter, J., dissenting) ("An Act for the elimination of diversity jurisdiction could fairly be called an Act for the relief of the federal courts.").

245. Robert H. Jackson, The Supreme Court in the American System of GovERNMENT 37 (1955).

246. Warren E. Burger, Annual Report on the State of the Judiciary, 62 A.B.A. J. 443, 444 (1976).

247. William H. Rehnquist, Chief Justice's 1991 Year-End Report on the Federal Judiciary, THIRD BRANCH, Jan. 1992, at 3.

248. Those judges include Dolores K. Sloviter (Third Circuit), Roger J. Miner (Second Circuit), Carl McGowan (D.C. Circuit), Clement F. Haynsworth, Jr. (Second Circuit), Wilfred Feinberg (Second Circuit), Henry J. Friendly (Second Circuit), and Howard C. Bratton (District Court, New Mexico). See Dolores K. Sloviter, A Federal Judge Views Diversity Jurisdiction Through the Lens of Federalism, 78 VA. L. REv. 1671, 1687 (1992); Roger J. Miner, The Tensions of a Dual Court System and Some Prescriptions for Relief, 51 Alb. L. Rev. 151, 158 (1987); Carl McGowan, Federal Jurisdiction: Legislative and Judicial Change, 28 Case W. Rsrv. L. Rev. 517, 531-33 (1978); Clement F. Haynsworth, Jr., Book Reviews, 87 Harv. L. Rev. 1082, 1088-91 (1974) (reviewing Henry J. Friendly, Fed- 
In light of this judicial and scholarly skepticism, it is necessary to discern whether a textually plausible interpretation of $\S 1332$ that restricts diversity jurisdiction is in fact aligned with congressional purpose, or whether, in its consistently narrow constructions of the diversity statute, the Supreme Court has subtly ignored congressional purpose. For the most part, the anti-diversity critics have focused on two related concerns: the overload of the federal courts' caseload ${ }^{249}$ and the diversion of the federal courts' resources away from issues of federal law. ${ }^{250}$

There are also other less common criticisms. Judge Dolores Sloviter, for example, examined "diversity jurisdiction's impact on the principles of federalism" 251 and concluded that diversity jurisdiction results in "the unavoidable intrusion of the federal courts in the lawgiving function of state courts." 252 Judge Roger Miner pointed out that diversity jurisdiction "creates unnecessary stress in our dual court system by making possible conflicting adjudications and procedural interferences." 253 Crucially, however, none of these diversity critics have at all concerned themselves with Congress's goals in creating a grant of original jurisdiction based on diversity.

In contrast, under a majordomo purposivist approach, the first task is to reverse-engineer Congress's purpose in enacting diversity jurisdiction. Most commentators agree that Congress's motivation was to protect against potential prejudice and bias of state courts against out-of-state citizens. James Madison explicitly asserted this rationale during the de-

eral Jurisdiction: A General View (1973)); Wilfred Feinberg, Is Diversity Jurisdiction an Idea Whose Time Has Passed?, N.Y. ST. B.J., July 1989, at 14, 14; FrIENDLy, supra at 139-52; Howard C. Bratton, Diversity Jurisdiction-An Idea Whose Time Has Passed, 51 IND. L.J. 347, 349 (1976). But see William M. Landes \& Richard A. Posner, Legal Change, Judicial Behavior, and the Diversity Jurisdiction, 9 J. Legal Stud. 367, 386 (1980) (presenting Judge Posner's view, based on the results of an empirical study, that "federal courts in diversity cases appear to make a significant contribution to the continuing development of the common law.").

249. See, e.g., FrIEndly, supra note 248, at 141 (noting "the problem of the volume of cases" in federal courts); JACKSON, supra note 245, at 37 ("[Diversity] cases are the major cause of congestion in federal courts ...."); Feinberg, supra note 248, at 14 ("[T] he continuation of diversity jurisdiction despite the current state of the docket of the federal courts is unjustifiable ...."); Frankfurter, A Note on Diversity Jurisdiction, supra note 243, at 1099 (noting a concern with "over-burdened federal dockets"); Haynsworth, supra note 248, at 1090 (noting that the removal of diversity jurisdiction "would be a tremendous gain for the effective functioning of the federal system").

250. See, e.g., Friendly, supra note 248 , at 141 ("The first and greatest single objection to the federal courts entertaining [diversity] actions is the diversion of judge-power urgently needed for tasks which only federal courts can handle or which, because of their expertise, they can handle significantly better than the courts of a state."); Kramer, supra note 236, at 102 (noting that "no other major class of cases has a weaker claim on federal judicial resources" than diversity cases); McGowan, supra note 248, at 533 (noting that diversity jurisdiction "draw[s] [federal courts'] energies away from the formulation of federal law to the ascertainment and application of state law."); Rehnquist, supra note 247, at 3 (suggesting as a means of preserving the federal courts" "scarce resources" the "elimination of diversity jurisdiction").

251. Sloviter, supra note 248, at 1671.

252. Id. at 1675 .

253. Miner, supra note 248, at 158; see also Kramer, supra note 236 at 105 ("[D]iversity jurisdiction is frequently a source of friction between state and federal courts."). 
bates at the time of the Constitution's drafting, expressing a concern that "a strong prejudice may arise, in some states, against the citizens of others, who may have claims against them." ${ }^{254}$ This purpose has been recognized by both the Supreme Court ${ }^{255}$ and legal scholars, including Professor Friedman. ${ }^{256}$

Not all commentators agree. Judge Henry Friendly, for example, argued that the Founders included a diversity jurisdiction clause in the Constitution "to protect creditors against legislation favorable to debtors." 257 Judge Friendly believed that the Framers' primary concern was that "courts of a state having laws favorable to debtors would apply these laws in favor of their own residents even though the debt was payable in another state" due to the close relationship between state legislatures and state judges. ${ }^{258} \mathrm{He}$ claimed "that there was little cause to fear that the state tribunals would be hostile to litigants from other states." 259 But despite this dissenting view, a majordomo purposivist judge would likely conclude that Congress was motivated by preventing bias towards out-ofstate litigants.

Over the years there have been several proposals to reduce or eliminate diversity jurisdiction. Twice in the 1930s, the Senate Judiciary Com-

254. 3 The Debates in the Several State Conventions, on the Adoption of the Federal Constitution, as Recommended by the General Convention at Philadelphia in 1787, at 533 (Jonathan Elliot ed., 2d ed. 1863); see also Yntema \& Jaffin, supra note 234, at $875 \mathrm{n} .12$ (noting that Madison made an "explicit statement in the Constitutional Convention, advocating inferior federal tribunals to obviate local prejudice in the state courts").

255. See, e.g., D’Oench, Duhme \& Co. v. FDIC, 315 U.S. 447, 466 (1942) (Jackson, J., concurring) ("[I]n diversity cases . . . federal jurisdiction exists to provide nonresident parties an optional forum of assured impartiality."); Barrow S.S. Co. v. Kane, 170 U.S. 100, 111 (1898) ("The object of the provisions of the Constitution and statutes of the United States, in conferring upon the Circuit Courts of the United States [diversity jurisdiction] ... was to secure a tribunal presumed to be more impartial than a court of the State in which one of the litigants resides."); Burgess v. Seligman, 107 U.S. 20, 34 (1883) ("[T]he very object of giving to the national courts jurisdiction to administer the laws of the States in controversies between citizens of different States was to institute independent tribunals which it might be supposed would be unaffected by local prejudices and sectional views .....); Bank of U.S. v. Deveaux, 9 U.S. (5 Cranch) 61, 87 (1809).

256. Friedman, supra note 5, at 25 ("The theoretical basis for diversity jurisdiction is that in a suit between citizens of the forum state and citizens of another state, state courts might be partial to their own citizens."); see also John P. Frank, The Case for Diversity Jurisdiction, 16 HaRv. J. ON LEGIS. 403, 406 (1979) ("The need [for diversity jurisdiction] arose from a fear of prejudice against out-of-staters engaged in regional business."); Comment, Diversity Jurisdiction for Unincorporated Associations, 75 Y ALE L.J. 138, 140 (1965) ("Originally [diversity] jurisdiction . . . was considered necessary to protect out-of-state litigants from local prejudice in state courts."); Warren, supra note 235 , at 83 ("The chief and only real reason for this diverse citizenship jurisdiction was to afford a tribunal in which a . . . citizen of another State might have the law administered free from the local prejudices or passions which might prevail in a State Court against . . . non-citizens.").

257. Friendly, supra note 235 , at $496-97$.

258. Id. at 496. More recently, Professor Roberts Jones posited that Congress was not concerned with state judges but instead did not trust state juries, and therefore preferred diversity jurisdiction because federal officials could better control the composition of federal juries. See Robert L. Jones, Finishing a Friendly Argument: The Jury and the Historical Origins of Diversity Jurisdiction, 82 N.Y.U. L. REv. 997, 1025 (2007).

259. Friendly, supra note 235 , at 497. 
mittee proposed legislation to limit diversity jurisdiction. ${ }^{260}$ In 1978, the House of Representatives passed a bill to abolish diversity jurisdiction, but the bill was not passed by the Senate. ${ }^{261}$ More recently, in 1990, the Federal Courts Study Committee proposed to significantly reduce the scope of diversity jurisdiction. ${ }^{262}$ Notably, however, none of these proposals became law; diversity jurisdiction survives today. Congress has only acted to reduce the scope of diversity jurisdiction by raising the minimum amount in controversy requirement -in 1958, 1988, and finally 1996 to its current $\$ 75,000$ amount. ${ }^{263}$ Congress has never eliminated diversity jurisdiction despite the constant pressure.

In fact, in recent years, Congress has actually expanded the scope of diversity jurisdiction. In 2005, Congress passed the Class Action Fairness Act (CAFA). ${ }^{264}$ While the diversity jurisdiction statute requires every plaintiff to be from a different state than every defendant (complete diversity), ${ }^{265}$ CAFA provides an exception. In large class actions (where the aggregated amount in controversy is greater than $\$ 5$ million), district courts have jurisdiction as long as "any member of a class of plaintiffs is a citizen of a State different from any defendant" (minimal diversity). ${ }^{266}$ Congress enacted CAFA to make it easier for class action defendants to access federal courts through diversity jurisdiction and more difficult for plaintiffs " "to "game" the procedural rules and keep nationwide or multistate class actions in state courts.' " 267 In sum, there is no indication, beyond the jurisdictional minimum, that Congress has ever decided to curtail diversity jurisdiction.

\section{The Complete Diversity Requirement}

On its face, $\S 1332$ is silent as to whether diversity jurisdiction calls for complete diversity, which would require that every plaintiff be from a different state than every defendant, or minimal diversity, which would just require that at least one plaintiff be from a different state than at least one defendant. ${ }^{268}$ In Strawbridge v. Curtiss, Chief Justice Marshall, in a one-page opinion, summarily concluded that diversity jurisdiction re-

260. McGowan, supra note 248, at 523.

261. Wright, Miller \& CoOper, supra note 235, § 3601, at 30. The bill was supported by Chief Justice Burger. Frank, supra note 256, at 403-04. On the other hand, many outside of the judiciary opposed the abolition of diversity jurisdiction, including nearly all of the ABA Board of Governors, the American Trial Lawyers Associations, and all fifty state bars. Id. at 404.

262. See The Fed. Cts. Study Comm., Report of the Federal Courts Study Committee (1990), reprinted in 22 Conn. L. Rev. 733, 781-82 (1990).

263. Wright, Miller \& CoOper, supra note 235, § 3601, at 5-7.

264. 28 U.S.C. $§ 1332(\mathrm{~d})$.

265. For a discussion of the complete diversity requirement, see infra Section V.B.1.

266. 28 U.S.C. $\S 1332(\mathrm{~d})(2)$.

267. Freeman v. Blue Ridge Paper Prods., Inc., 551 F.3d 405, 408 (6th Cir. 2008) (quoting S. Rep. No. 109-14, at 4 (2005)).

268. See Wright, Miller \& Cooper, supra note 235, § 3605, at 185 ("The statutory grant of diversity of citizenship jurisdiction in [28 U.S.C. $\$ 1332$ ] contains few express guidelines for determining whether diversity exists in cases involving multiple parties."). 
quires complete diversity. ${ }^{269}$ Consequently, the Court has adhered to this view. Crucially, Chief Justice Marshall did not examine the text of the diversity statute or Congress's policy motivations for enacting diversity jurisdiction. Indeed, Chief Justice Marshall provided no rationale for his opinion whatsoever. It was not until 150 years later that the Court even determined whether Chief Justice Marshall had been interpreting Article III or the diversity statute: in State Farm Fire \& Casualty Co. v. Tashire, the Court held that the complete diversity requirement derived from $\S 1332$ and not the Constitution. ${ }^{270}$ But in so doing, the Court again did not discuss the statute's text or congressional purpose. ${ }^{271}$

A majordomo purposivist judge would reject the Court's analysis from a pure institutionalist perspective, without reaching the normative criticisms of complete diversity. In holding that $\S 1332$ requires complete diversity without any examination of congressional purpose, the Court violated core principles of democratic theory and separation of powers. It is the job of the legislature, the democratically elected representative body, to create-within constitutional boundaries-substantive jurisdictional policy; it is the judiciary's job to interpret and apply those policies to the best of its ability. In judicially creating a complete diversity requirement without examining Congress's motivations behind the diversity statute, the Court usurps that legislative role.

Because nothing in the text of $\S 1332$ speaks to whether complete diversity is required, a judge acting as majordomo purposivist would reverse-engineer congressional purpose before determining whether complete or minimal diversity is appropriate. In performing this task, a majordomo purposivist judge would understand that Congress's purpose in creating diversity jurisdiction was to protect out-of-state litigants from state court prejudice. Thus, the judge would determine whether the complete diversity requirement best effectuates that purpose, or if instead, a minimal diversity requirement would better fulfill Congress's desires. ${ }^{272}$ Because the risk of prejudice to an out-of-state plaintiff remains even if, for example, there is an additional plaintiff from the same state as the defendant, a majordomo purposivist judge would choose a minimal diversity requirement.

It is true that today Congress seems to understand the diversity statute to require complete diversity. Most notably, Congress has on three occasions statutorily abrogated the complete diversity requirement. ${ }^{273}$ By requiring minimal diversity in specific instances, Congress implicitly accepts

269. Strawbridge v. Curtiss, 7 U.S. (3 Cranch) 267, 267 (1806).

270. State Farm Fire \& Cas. Co. v. Tashire, 386 U.S. 523, 530-31 (1967).

271. See id. at 525-38.

272. See David P. Currie, The Federal Courts and the American Law Institute Part I, 36 U. CHI. L. Rev. 1, 19 (1968) ("If one is really concerned with providing a federal forum to protect a foreign litigant from possible bias, a re-examination of Strawbridge is in order ....").

273. See 28 U.S.C. $\S 1335$ (federal interpleader statute); 28 U.S.C. $§ 1369$ (Multiparty, Multiform Trial Jurisdiction Act); 28 U.S.C. § 1332(d) (Class Action Fairness Act). 
the Court's holdings recognizing the complete diversity requirement. But while the statutory adoption of minimal diversity in specific circumstances may suggest that Congress is okay with the complete diversity requirement, Congress has never, through bicameralism and presentment, statutorily adopted it.

Indeed, Professor Friedman explicitly acknowledged that "decisions regarding diversity jurisdiction provide an example of the Court determining jurisdiction without serious attention to, or concern for, congressional intent." 274 A majordomo purposivist judge would reject this disregard of congressional purpose.

\section{Citizenship of Unincorporated Entities}

The Court's current jurisprudence surrounding the citizenship of unincorporated organizations for purposes of diversity jurisdiction can also be critiqued from a majordomo purposivist perspective. In determining the citizenship of unincorporated organizations, the Court has consistently hidden its normative policy preference behind a supposed rigid obligation to congressional intent. ${ }^{275}$ But this purported deference to Congress is manipulative and improper. Unlike corporations, Congress has not defined the citizenship of unincorporated entities for purposes of diversity. ${ }^{276}$ Instead, the Court has adhered to its own judge-made doctrine.

In Chapman v. Barney, the Court first announced a judicially created rule that citizenship of unincorporated organizations is determined by the citizenship of all of the organization's members. ${ }^{277}$ In other words, an unincorporated organization has citizenship in every state it has members; diversity jurisdiction is unavailable if any member is from the same state as the opposing party. In reaching this conclusion, the Chapman Court did not consider whether the rule would be consistent with Congress's reasons for creating diversity jurisdiction. ${ }^{278}$ The Court has affirmed this rule for other unincorporated entities such as labor unions, ${ }^{279}$ limited partnerships, ${ }^{280}$ and unincorporated business trusts. ${ }^{281}$ Additionally, courts of appeals have applied the rule to limited liability companies. ${ }^{282}$ In applying the Chapman rule to other unincorporated entities,

274. Friedman, supra note 5, at 25-26.

275. See infra notes $277-92$ and accompanying text.

276. Congress has explicitly defined the citizenship of corporate entities for diversity jurisdiction purposes: "[A] corporation shall be deemed to be a citizen of every State and foreign state by which it has been incorporated and of the State or foreign state where it has its principal place of business" 28 U.S.C. $\S 1332$ (c)(1). Thus, a majordomo purposivist has no difficulty determining the domicile of corporations; Congress's directive is clear, and a majordomo judge just needs to adhere to the unambiguous text.

277. Chapman v. Barney, 129 U.S. 677, 682 (1889).

278. See id. at $678-82$.

279. United Steelworkers of Am. v. R.H. Bouligny, Inc., 382 U.S. 145, 153 (1965).

280. Carden v. Arkoma Assocs., 494 U.S. 185, 197 (1990).

281. Americold Realty Tr. v. ConAgra Foods, Inc., 136 S. Ct. 1012, 1017 (2016).

282. See Grupo Dataflux v. Atlas Glob. Grp., 541 U.S. 567, 585 n.1 (2004) (Ginsburg, J., dissenting) ("Although the Court has never ruled on the issue, Courts of Appeals have held the citizenship of each member of an LLC counts for diversity purposes."); see also, 
the Court has made itself appear seemingly powerless, claiming that it could not alter the Chapman rule without congressional action.

For example, when the Court applied the Chapman rule to labor unions, it noted the "dissatisfaction" with the rule among both lower federal courts and scholars, conceded that "labor unions are indistinguishable from corporations in terms of the reality of function and structure," and recognized that the distinction between corporations and unincorporated associations is "artificial and unreal." 283 Nevertheless, the Court concluded that "these arguments, however appealing, [were] addressed to an inappropriate forum, and that pleas for extension of the diversity jurisdiction ... ought to be made to the Congress and not to the courts." 284 The Court stressed that Congress, which did enact legislation regarding the citizenship of corporations, declined to address unincorporated associations. ${ }^{285}$ Thus, the Court concluded that "[w]hether unincorporated labor unions ought to be assimilated to the status of corporations for diversity purposes, how such citizenship is to be determined, and what if any related rules ought to apply, are decisions ... suited to the legislative and not the judicial branch." 286

Similarly, in determining the citizenship of a limited partnership, the Court "adhere[d] to [the] oft-repeated rule that diversity jurisdiction . . . depends on the citizenship of 'all the members.' "287 Despite recognizing that "considerations of basic fairness and substance over form require that limited partnerships receive similar treatment" as corporations, ${ }^{288}$ the Court concluded that only Congress could implement a new diversity jurisdiction policy for non-corporate commercial organizations. ${ }^{289}$ The Court even conceded that while Congress explicitly provided for "special treatment for corporations," it enacted "[n]o provision . . . for the treatment of artificial entities other than corporations." 290 Nevertheless, the Court hid behind a disingenuous deference to Congress to shield its own judge-made doctrine. ${ }^{291}$ The Court recently came to the same conclusion

\footnotetext{
e.g., Harvey v. Grey Wolf Drilling Co., 542 F.3d 1077, 1080 (5th Cir. 2008) ("All federal appellate courts that have addressed the issue have reached the same conclusion: like limited partnerships and other unincorporated associations or entities, the citizenship of a[n] LLC is determined by the citizenship of all of its members." (citing opinions from eight circuits)).

283. R.H. Bouligny, 382 U.S. at 149-50.

284. Id. at $150-51$.

285. See id. at 152 .

286. Id. at 153 .

287. Carden v. Arkoma Assocs., 494 U.S. 185, 195 (1990) (quoting Chapman v. Barney, 129 U.S. 677, 682 (1889)).

288. Id. at 196 .

289. Id. at 197.

290. Id. at $196-97$.

291. See id. at 197 ("[T] he course we take today does not so much disregard the policy of accommodating our diversity jurisdiction to the changing realities of commercial organization, as it honors the more important policy of leaving that to the people's elected representatives. Such accommodation is not only performed more legitimately by Congress than by courts, but it is performed more intelligently by legislation than by interpretation of the statutory word 'citizen.'”).
} 
for unincorporated trusts, "reaffirm[ing] that it is up to Congress if it wishes to incorporate other entities into 28 U.S.C. $\$ 1332$ (c)'s special jurisdictional rule" defining the citizenship of corporations. ${ }^{292}$

One can be reasonably skeptical of the Court's purported deference to congressional intent. Even though the Court did not even attempt to examine congressional purpose when creating the rule in Chapman, the Court has claimed time and time again that it cannot alter the rule on citizenship of unassociated organizations without congressional consent. The Court has failed to recognize that the Chapman rule was wholly judge-made. While Congress did act to define the citizenship of corporations, for whatever reason, it chose not to comment on unincorporated associations. ${ }^{293}$ Judge-made rules do not become law by congressional inaction, ${ }^{294}$ and while the Court must adhere to legislative rules, principles of democratic theory and separation of powers in no way preclude the Court from overturning its own judge-made rules. ${ }^{295}$ The Court appears to have made its own normative choice to constrain diversity jurisdiction. In order to present itself as powerless to make a change and insulate itself from any criticism of its decision, the Court chose to invoke principles of separation of powers, purportedly adhering to legislative directives that, in reality, do not exist. ${ }^{296}$

A majordomo purposivist judge would acknowledge that Congress did not mandate the rule that citizenship of unincorporated associations is based on the citizenship of each of its members and recognize that $\S 1332$ does not speak to this issue. While it is true that the rule the Court created in Chapman and affirmed in Bouligny, Carden, and Americold is a plausible interpretation of the text, it is by no means mandatory. From a majordomo purposivist approach, a Court would develop a rule for citi-

292. Americold Realty Tr. v. ConAgra Foods, Inc., 136 S. Ct. 1012, 1017 (2016).

293. See Peter B. Oh, A Jurisdictional Approach to Collapsing Corporate Distinctions, 55 Rutgers L. Rev. 389, 431 (2003) ("Congress, however, has not extended the presumption of corporate citizenship to unincorporated associations."); Diversity Jurisdiction for Unincorporated Associations, supra note 256, at $147 \mathrm{n} .50$. ("There is no indication that Congress even considered the status of unincorporated associations in 1958 . ..."); Comment, Citizenship of Unincorporated Associations for Diversity Purposes, 50 VA. L. Rev. $1135,1136 \mathrm{n} .16$ (1964) (noting that $\S 1332$ (c) applied only to corporations and "unincorporated associations were not considered.").

294. See Diversity Jurisdiction for Unincorporated Associations, supra note 256, at 147 $\mathrm{n} .50$ ("[T] 1958 is not equivalent to congressional action denying them citizenship for jurisdictional purposes.").

295. See Reimann v. Monmouth Consol. Water Co., 87 A.2d 325, 333 (N.J. 1952) (Vanderbilt, C.J., dissenting) ("[W]hen a rule has been established by legislation, however undesirable it may be, it is for the Legislature alone to remedy the situation . . . . But when the rule is one of common law established by the courts the remedy lies with either the Legislature or the courts, and inaction by one does not preclude action by the other.").

296. See Redish, Abstention, supra note 28, at 104 \& n.144 (citing the Court's "determination that, for purposes of diversity, a private association's citizenship is citizenship of each of its members" as an example of the Court "construing the terms of the diversity grant [to] develop[ ] principles of questionable logic that function only to serve the thinlyveiled goal of curbing the scope of the diversity grant"). 
zenship of unincorporated organizations that best effectuates congressional purpose in creating diversity jurisdiction.

Assuming that diversity jurisdiction was created to combat hostility toward out-of-state litigants, a majordomo purposivist would suggest an interpretation that prevents out-of-state associations from facing state court bias. A majordomo purposivist judge would recognize that the Chapman rule does not effectuate this goal. ${ }^{297}$ Indeed, the risk of local prejudice against out-of-state litigants is especially strong where the out-of-state litigant is a labor union, as was the case in Bouligny. The Court, though shirking its responsibility by mindlessly deferring to Congress, found "appealing" the petitioner's arguments that "when the nonresident defendant is a major union, local juries may be tempted to favor local interests at its expense. [They] may also be influenced by the fear that unionization would adversely affect the economy of the community and its customs and practices in the field of race relations." 298 And scholars have recognized that state courts are "often antiunion." 299 But due to the complete diversity requirement, the Chapman rule completely precludes federal jurisdiction for many unincorporated associations. ${ }^{300}$ Such a result is not consistent with Congress's motivation for creating diversity jurisdiction.

A majordomo purposivist, recognizing that the Chapman rule is contrary to congressional purpose, would suggest a rule similar to that enacted by Congress for corporations. Majordomo purposivist judges would determine that they could best effectuate congressional purpose by defining unincorporated entities' citizenship based on their principal place of business. Such a rule would best adhere to Congress's goal of creating diversity jurisdiction to protect out-of-state litigants from state court bias. Additionally, the rule would treat corporate and unincorporated entities the same, recognizing that they both face similar risks of bias in state court. $^{301}$

297. See Diversity Jurisdiction for Unincorporated Associations, supra note 256, at 143 ("The Chapman rule is inconsistent with the functions of diversity jurisdiction since it prevents access to a federal court if merely one of the hundreds or thousands of members of an association is a citizen of the same state as an opposing party.").

298. United Steelworkers of Am. v. R.H. Bouligny, Inc., 382 U.S. 145, 150 (1965).

299. Nathan Newman, The Conflict of the Courts: RICO, Labor, and Legal Preemption in Union Comprehensive Campaigns, 51 DraKe L. Rev. 307, 331 (2003); see also Comment, Fair Representation and Breach of Contract in Section 301 Employee-Union Suits: Who's Watching the Back Door?, 122 U. PA. L. Rev. 714, 715 n.7 (1974) (noting the "fear of antiunion sentiment in state courts"); Clyde W. Summers, Freedom of Association and Compulsory Unionism in Sweden and the United States, 112 U. PA. L. REv. 647, 684 (1964) (noting the "general judicial hostility to unions" in state courts).

300. See Mullenix, Redish \& Vairo, supra note 155, at 175 ("[I]t will be highly unlikely that a nationally based association will meet the complete diversity requirement because it is likely that some members will share the citizenship of a party on the other side of the action.").

301. See Diversity Jurisdiction for Unincorporated Associations, supra note 256, at 147 (noting that "the functions Congress intended the 1958 legislation to serve would be served also by treating unincorporated associations as citizens of their principal place of business" and that such a rule "allow[s] similar entities to be treated similarly"). 


\section{Jurisdictional Amount and Aggregation of Claims}

From a majordomo purposivist perspective, the current standard for aggregating multiple litigants' claims into a single cause of action to meet the statutory jurisdictional minimum for diversity jurisdiction would also be rejected. As in the context of citizenship of unincorporated associations, the Court wraps itself in congressional intent in order to insulate its adoption of its own judge-made policy preferences from critique.

The diversity statute states that for a court to exercise diversity jurisdiction, the "matter in controversy" must exceed a certain minimum, which today sits at $\$ 75,000 .{ }^{302}$ Congress did not speak to whether multiple plaintiffs can aggregate their claims within a single cause of action to meet the jurisdictional minimum. The Court answered this question in 1911, and again in 1916, with a judge-made rule. It summarily concluded that where plaintiffs' claims are joint, they can aggregate their claims to meet the jurisdictional minimum; but where plaintiffs' claims are "separate and distinct," they may not. ${ }^{303}$ In reaching these decisions, the Court did not at all examine the plain language of, or congressional purpose behind, the diversity statute and the "matter in controversy" requirement. Indeed, the Court did not perform any analysis whatsoever. In reality, based on the rule that aggregation turns on the joint (common or undivided) versus several (separate and distinct) dichotomy, plaintiffs can rarely aggregate their claims because courts almost never determine that claims are "joint."304

The Court had the opportunity to reconsider the joint-versus-several dichotomy in Snyder v. Harris in the context of whether class action plaintiffs with "separate and distinct claims" could aggregate their claims to reach the jurisdictional amount in controversy.305 The Court, while correctly recognizing that "[i]t is linguistically possible ... to interpret the old congressional phrase "matter in controversy" "306 to either allow or disallow the aggregation of claims, affirmed the joint-versus-several distinction. The Court determined that it must adhere to its own "consis-

302. 28 U.S.C. $\S 1332(\mathrm{a})$.

303. See Troy Bank v. G.A. Whitehead \& Co., 222 U.S. 39, 40-41 (1911) ("When two or more plaintiffs, having separate and distinct demands, unite for convenience and economy in a single suit, it is essential that the demand of each be of the requisite jurisdictional amount; but when several plaintiffs unite to enforce a single title or right, in which they have a common and undivided interest, it is enough if their interests collectively equal the jurisdictional amount." (emphasis added)); Pinel v. Pinel, 240 U.S. 594, 596 (1916) (same).

304. See Wright, Miller \& CoOper, supra note 235, § 3704 at 576-77, 584; Redish, supra note 206, at 1807.

305. Snyder v. Harris, 394 U.S. 332, 333 (1969).

306. Id. at 338. The Court was also correct to reject the argument that the joint and several dichotomy should be set aside merely because the 1966 amendment to Rule 23 of the Federal Rules of Civil Procedure replaced the formalistic joint and several categories with a more functional approach. As the Court properly recognized, "[ $\mathrm{t}$ ]he doctrine that separate and distinct claims [cannot] be aggregated ... is not ... based upon the categories of old Rule 23 or of any rule of procedure ... [but] is based rather upon [the] Court's interpretation of the statutory phrase 'matter in controversy.' " Id. at 336. Indeed, the Federal Rules of Civil Procedure cannot alter federal courts' jurisdiction. FED. R. CIV. P. 82 ("These rules do not to extend or limit the jurisdiction of the district courts . ..."). 
tent[ ] interpret[ation] [that] the jurisdictional statute passed by Congress [does] not confer[] jurisdiction where the required amount in controversy can be reached only by aggregating separate and distinct claims." 307

In so doing, the Court claimed that its hands were tied and that if the rule were to be changed, it must be changed by Congress. ${ }^{308}$ It justified its holding by concluding that " $[\mathrm{w}]$ here Congress has consistently re-enacted its prior statutory language for more than a century and a half in the face of a settled interpretation of that language, it is perhaps not entirely realistic to designate the resulting rule a 'judge-made formula.' "309 And it therefore concluded that it was up to Congress, and not the Court, to change the "established aggregation principles." 310 But the Court's reasoning is flawed: Congress has never codified any sort of rule as to whether or not multiple plaintiffs can aggregate their claims in order to reach the jurisdictional minimum. ${ }^{311}$ Instead, the Court made a normative policy decision to restrict diversity jurisdiction through a judge-made doctrine, and then claimed it could not alter that policy choice based on a selective deference to Congress and adherence to principles of separation of powers. The preference and manipulation are not a surprise given the anti-diversity bias expressed by the federal judiciary.

In contrast, majordomo purposivist judges would not claim to be deferring to Congress to affirm what amounts to their own judge-made doctrine. The majordomo purposivist judge would consider Congress's motivation in creating the "matter in controversy" requirement and would determine the appropriate aggregation rules to best effectuate that purpose. The Court in Snyder seemed to at least somewhat examine congressional purpose, noting that Congress's goal "was to check, to some degree, the rising caseload of the federal courts." 312 But the Court's analysis was incomplete. More specifically, Congress created the matter in controversy requirement to restrict the availability of diversity to causes of action that reach a certain level of financial worth. ${ }^{313}$ While naturally, the restriction reduces the quantity of federal diversity cases, this result is a byproduct of the amount in controversy requirement, not necessarily a principal motivation.

307. Snyder, 394 U.S. at 338.

308. Id. at 341-42.

309. Id. at 339 .

310. Id. at 341-42.

311. It is true that Congress has codified a jurisdictional minimum for diversity actions and has increased that minimum overtime. Id. at 338-39. But the mere existence of a jurisdictional minimum in no way indicates Congress's preferred method of aggregating multiple plaintiffs' claims to reach that minimum. See Redish, supra note 206, at 1809 . Moreover, the fact that Congress has reenacted the same statutory language without commenting on or rejecting the Court's aggregation rules is irrelevant and does not indicate agreement; congressional silence is not akin to policymaking. Id.

312. Snyder, 394 U.S. at 339-40.

313. See Wright, Miller \& CoOper, supra note 235, § 3701, at 601 ("[T]he basic purpose of the amount in controversy requirement is to ensure that the federal courts adjudicate only those diversity controversies that appear to be substantial ...."). 
Majordomo purposivist judges, using their common sense and implementational discretion, would determine that permitting multiple litigants to aggregate their claims in a single cause of action - and not basing aggregation rules on the archaic joint-versus-several dichotomy-best effectuates Congress's purpose in creating a matter in controversy requirement for two reasons. First, the financial substantiality of a cause of action does not turn on whether each individual plaintiff meets the minimum amount in controversy. In other words, if several plaintiffs' smaller claims in a single cause of action aggregate to an amount in controversy greater than the statutory minimum, that cause of action is just as substantial as if one plaintiff's claim was greater than the minimum.

Second, there is no indication that Congress would prefer the minimum amount in controversy determination to turn on the imprecise and confusing "joint" versus "separate and distinct" dichotomy. The joint versus separate and distinct determination is an antiquated, formalistic dichotomy that makes little practical sense; the meaning of those terms is impossible for a judge to determine. ${ }^{314}$ Despite the fact that the petitioner in Snyder raised both of these arguments, ${ }^{315}$ the Court refused to reach their merits, instead selectively deferring to Congress to make any change.

In sum, majordomo purposivist judges would recognize that the current aggregation rules are exclusively judge-made and would not evade their responsibility in determining whether the joint-versus-several dichotomy is the appropriate rule. In the face of congressional silence, the Court has the responsibility and ability to change its own prior rule to better effectuate congressional purpose. The judiciary can best effectuate Congress's purpose in enacting, as part of $\S 1332$, a matter in controversy requirement by abandoning the joint-versus-several distinction and allowing aggregation of several plaintiffs' claims. By selectively and inappropriately deferring to Congress, the Court impairs the availability of diversity jurisdiction while trying to dodge responsibility for its normative policy preference.

314. See Morrison v. Allstate Indem. Co., 228 F.3d 1255, 1262 (11th Cir. 2000) (noting the "pervasive criticism of the 'separate and distinct' versus 'common and undivided' distinction as arcane and confusing"); Aetna Cas. \& Sur. Co. v. Graves, 381 F. Supp. 1159, 1162 (W.D. La. 1974) ("We . . realize that the rules on aggregation of claims to satisfy the requirements of minimum amount in controversy '. . . turn on a mystifying conceptual test." " (second alteration in original) (quoting Wright, LAW OF FEDERAL CourTs, § 36, at 112)); see also FED. R. CIV. P. 23 advisory committee's note to 1966 amendment ("In practice, the terms 'joint,' 'common,' etc., . . . proved obscure and uncertain."); Benjamin Kaplan, Continuing Work of the Civil Committee: 1966 Amendments of the Federal Rules of Civil Procedure (I), 81 Harv. L. Rev. 356, 380 (1967) ("[T]he terms 'joint,' 'common,' and 'several' have little or no clear and ascertainable meaning ....").

315. Snyder, 394 U.S. at 338 (noting that the petitioner's arguments were "(1) the determination of whether claims are 'separate and distinct' is a troublesome question that breeds uncertainty and needless litigation, and (2) the inability of parties to aggregate numerous small claims will prevent some important questions from being litigated in federal courts"). 


\section{CONCLUSION}

Much has been written about the Court's troubling federal question and diversity jurisdiction doctrines. The Court tends to usurp the congressional responsibility to create jurisdictional policy by either ignoring the congressional purpose motivating the statutes or claiming to be restricted by some imaginary congressional command. This Article highlights that, at bottom, the Court's flawed federal question and diversity jurisdiction doctrines stem from an improper approach to statutory interpretation.

The Court's current statutory interpretation technique reflects a partnership-like model, permitting courts to arrogate to themselves what can only be described as legislative power. Indeed, Professor Friedman proposed the dialogic approach for the very purpose of describing the judiciary's partnership role. Partnership models of statutory interpretation are flawed because they permit the federal courts to create jurisdictional doctrine based on their own policy preferences in violation of principles of democratic theory and separation of powers.

We propose the majordomo purposivist approach not to revolutionize statutory interpretation, but instead, to promote a means by which the courts are able to function as common-sense agents of Congress. While ultimately subordinate to Congress, majordomo purposivist judges may need to utilize their implementational discretion to arrive at the interpretation which they truly believe best effectuates the congressional purpose animating a statute. Even the most hesitant acceptance of the majordomo purposivist precept requires the Court to rethink its approach to statutory interpretation in federal question and diversity jurisdiction cases, and thereby rethink federal question and diversity jurisdiction doctrine as a whole. 